\title{
The metamorphic rocks of the Nunatak Viedma in the Southern Patagonian Andes: Provenance sources and implications for the early Mesozoic Patagonia-Antarctic Peninsula connection
}

\author{
Rodrigo J. Suárez ${ }^{\mathrm{a}, *}$, Matías C. Ghiglione ${ }^{\mathrm{a}}$, Mauricio Calderón ${ }^{\mathrm{b}}$, Christian Sue $^{\mathrm{c}}$, Joseph Martinod ${ }^{\mathrm{d}}$, \\ Benjamin Guillaume ${ }^{\mathrm{e}}$, Diego Rojo ${ }^{\mathrm{f}}$ \\ ${ }^{\mathrm{a}}$ Instituto de Estudios Andinos IDEAN (Universidad de Buenos Aires - CONICET), Buenos Aires, Argentina \\ b Carrera de Geología, Facultad de Ingeniería, Universidad Andres Bello, Sazié 2119, Santiago, Chile \\ ${ }^{\mathrm{c}}$ CNRS-UMR6249, Université de Bourgogne Franche-Comté, 16 route de Gray, 25030, Besançon Cedex, France \\ ${ }^{\mathrm{d}}$ ISTerre, Université de Savoie Mont-Blanc, 73376, Le Bourget du Lac cedex, France \\ e Université Rennes, CNRS, Géosciences Rennes - UMR 6118, F-35000, Rennes, France \\ ${ }^{\mathrm{f}}$ Facultad de Ingenieria y Arquitectura, Universidad Arturo Prat, Iquique, Chile
}

\section{A R T I C L E I N F O}

\section{Keywords:}

\section{Nunatak Viedma}

Very-low grade metamorphic rocks

Detrital zircons ages

Antarctic Peninsula

Southern Patagonian Andes

Southwestern Gondwana

\begin{abstract}
A B S T R A C T
The Nunatak Viedma within the Southern Patagonian Icefield has been considered as a volcanic center based on its geomorphologic features, despite the fact that field explorations by Eric Shipton determined its metamorphic nature 70 years ago. We carried out fieldwork to characterize this isolated outcrop and performed the first U-Pb dating in detrital zircons from the basement rocks located inside the Southern Patagonian Icefield. We recognized very-low grade metamorphic rocks, corresponding principally to metapelites and metapsammites, and scarce metabasites. Detrital zircons in three metapsammitic samples (composite group of 240 grains) yielded prominent age population peaks at $\sim 1090, \sim 960, \sim 630, \sim 520, \sim 480-460, \sim 380, \sim 290-260, \sim 235-225 \mathrm{Ma}$ that are typical of Gondwanide affinity, and youngest grains at $\sim 208 \mathrm{Ma}$. Maximum depositional ages of 225, 223 and 212 Ma were calculated for each sample from the youngest cluster of ages. This distinctive and novelty Late Triassic age justifies differentiate the Nunatak Viedma Unit from the Devonian-early Carboniferous and Permian-Early Triassic (?) belts of the Eastern Andean Metamorphic Complex. Possible primary source areas for the detrital zircons are outcropping in southern Patagonia, the Antarctic Peninsula, and the Malvinas Islands. Additionally, secondary sources could be part of the erosion and recycling of metasediments from the Eastern Andean Metamorphic Complex. We propose that the cluster of Triassic ages is related to the volcanic arc emplaced along the Antarctic Peninsula and active at that time when was still attached to southern Patagonia during the Triassic. The dynamics of the early Mesozoic orogen is also discussed.
\end{abstract}

\section{Introduction}

The Nunatak Viedma located in the Southern Patagonian Icefield (Fig. $1 ; 49^{\circ} 22^{\prime} \mathrm{S}, 73^{\circ} 19^{\prime} \mathrm{W}$ ), has been considered as an active volcano because of its geomorphologic features, which resemble a group of volcanoes (Lliboutry, 1956; Mazzoni et al., 2010). The early descriptions were based on the first aerial survey that covered the Patagonian icefields (Lliboutry, 1956). Shipton (1960, 1963), however, undertook a field investigation between 1958 and 1962 recognizing that the Nunatak Viedma is entirely composed of metamorphic rocks partially cover by quaternary deposits, mentioning that "there was no sign whatever of any volcanic activity". Nevertheless, some technical works were recently carried out to characterize the composition and geomorphology of this supposed volcano (Kilian, 1990; Kobashayi et al., 2010). On the other hand, mapping by the Argentine Geological-Mining Survey (SEGEMAR; Giacosa et al., 2012a) assigned this out crop to the late Paleozoic Bahía de la Lancha Formation. By last, Blampied et al. (2012) described it as a folded metasedimentary sequence composed of schists and gneisses, assigning their particular geomorphological volcanic-like shape to glacial processes.

Metamorphic rocks of the Southern Patagonian Andes principally include low-grade, metasedimentary units grouped in two distinctive,

\footnotetext{
* Corresponding author. Instituto de Estudios Andinos IDEAN (Universidad de Buenos Aires - CONICET). Intendente Güiraldes 2160 Ciudad Universitaria - Pabellón II, C1428EGA, CABA, Argentina.

E-mail addresses: rodrigo_s_37@hotmail.com, rsuarez@gl.fcen.uba.ar (R.J. Suárez).
} 

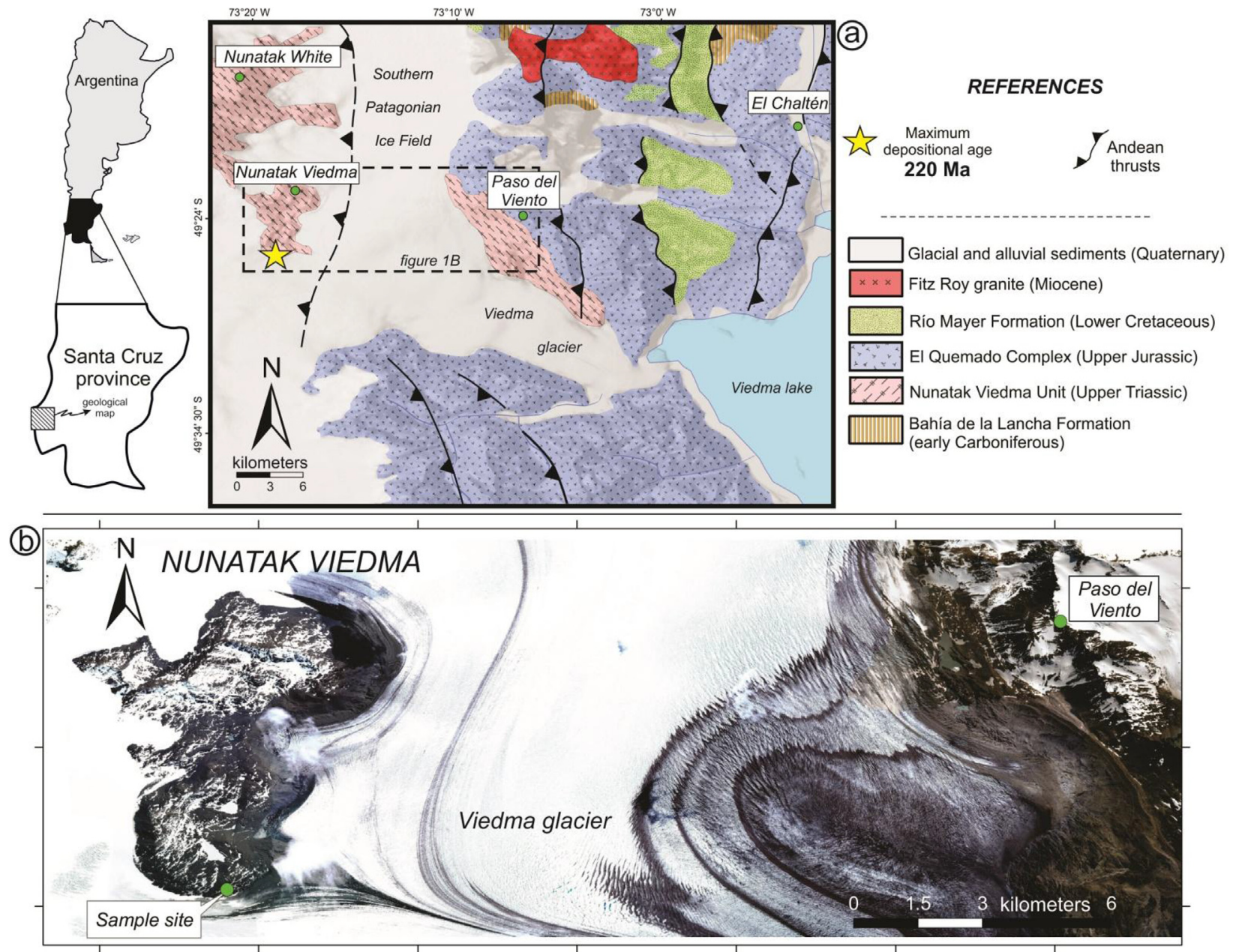

Fig. 1. (a) Location and geological map of the study area (modified from Giacosa et al., 2012b). The yellow star corresponds to the U-Pb detrital zircons sampling site. (b) Zoom-in on the Nunatak Viedma-Paso del Viento showing with major precision the sample site. (For interpretation of the references to colour in this figure legend, the reader is referred to the Web version of this article.)

north-south oriented, Eastern and Western complexes flanking the Patagonian Batholith (Hervé et al., 2003, 2008; Calderón et al., 2016). Deposition of the protoliths and subsequent metamorphism and deformation occurred between the late Paleozoic and the early Mesozoic (Hervé et al., 2008). In the widespread distributed Eastern Andean Metamorphic Complex (EAMC), the protoliths were deposited during the Late Devonian-early Carboniferous and Late Permian-Early Triassic (Hervé et al., 2003; Augustsson et al., 2006) and metamorphosed, at least the older units, during the Gondwanide orogeny (Thomson and Hervé, 2002; Giacosa et al., 2012a,b; Heredia et al., 2016). In this vast metamorphic complex were included the Bahía de la Lancha and Río Lácteo formations defined in the Argentinean territory (Hervé et al., 2008). A regionally widespread angular unconformity with the overlying Upper Jurassic volcano-sedimentary rocks along the Patagonian hinterland (Ghiglione et al., 2009; Giacosa et al., 2012a,b; Zerfass et al., 2017), gives a minimum age for deformation of the folded basement units.

On the other hand, units of the western Metamorphic Complexes exhibit a geological history related to subduction dynamics and accretion of exotic terranes during the Triassic-Jurassic (Hervé et al., 2003, 2008; Hervé and Fanning, 2001; Willner et al., 2009; Angiboust et al., 2017).

From correlation of Paleozoic-early Mesozoic magmatic and tectometamorphic events (Pankhurst et al., 2003; Hervé et al., 2006; Castillo et al., 2016; Heredia et al., 2016, 2018; Riley et al., 2016; González et al., 2018), it has been proposed that South America, Patagonia, and the Antarctic Peninsula were contiguous regions forming the SW margin of Gondwana. In this sense, several authors have discussed the spatial relation between Patagonia and the Antarctic Peninsula (Fig. 2; Suárez, 1976; Harrison et al., 1979; Lawver et al., 1998; Hervé and Fanning, 2003; Hervé et al., 2006; Ghidella et al., 2007; Calderón et al., 2016; Heredia et al., 2016) conforming the Terra Australis Orogen before Gondwana breakup (Fig. 2; Suárez, 1976; Harrison et al., 1979; Miller et al., 1987, 2007; Lawver et al., 1992, 1998; Jokat et al., 2003; König and Jokat, 2006; Ghidella et al., 2007). The "tight-fit" model of Lawver et al. (1998) suggests that the northern edge of the Antarctic Peninsula was located near the current Golfo de Penas (Fig. 2), although clear correlations between Patagonian and the Antarctic Peninsula are still missing to validate this hypothesis (Hervé et al., 2006). After the onset of oceanic spreading, lateral displacements and block rotations during Mesozoic-Cenozoic times, including opening of the Scotia plate, determined the current plate configuration and the distribution of the continental fragments of Gondwana (Suárez, 1976; Harrison et al., 1979; Jokat et al., 2003; Eagles, 2016; Ghiglione et al., 2016).

In this contribution, we provide a lithological characterization and $\mathrm{U}-\mathrm{Pb}$ zircon detrital ages from metasedimentary rocks of the Nunatak Viedma and discuss its evolution within the geodynamic context of the SW edge of Gondwana. The distinctive Late Triassic age justifies to differentiate a Nunatak Viedma Unit (NVU) separate from the EAMC. Furthermore, we discuss the possible sedimentary sources for the protolith of the NVU and its implications for the paleogeography and location of the Antarctic Peninsula with respect to Patagonia during 


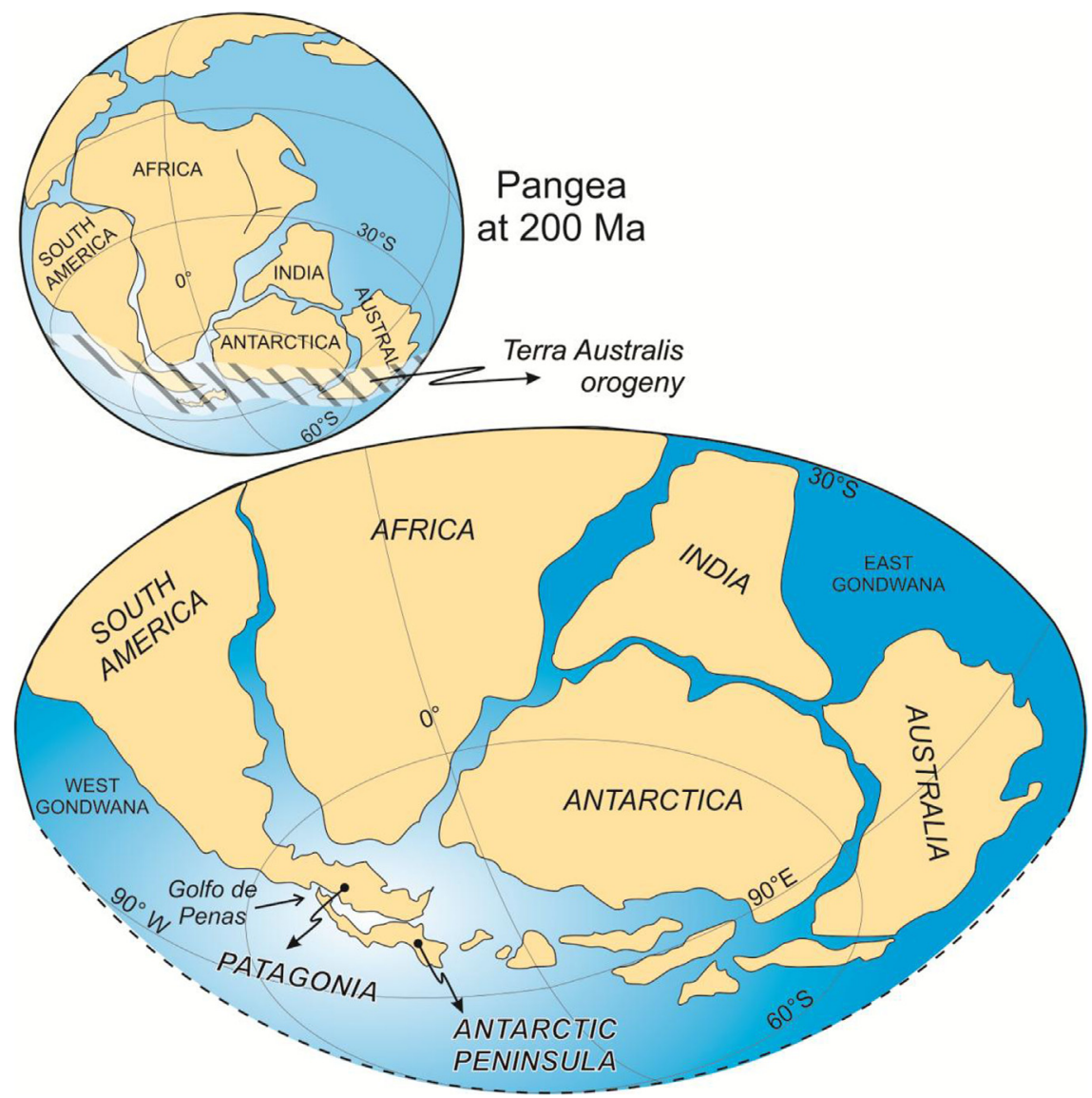

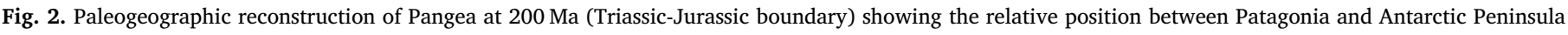
(modified from the "tight fit model" by Lawver et al., 1998).

Triassic times.

\section{Geodynamic context}

The Terra Australis Orogen developed along the active margin of Gondwana during Neoproterozoic-early Mesozoic times (Fig. 2; Cawood, 2005; Cawood and Buchan, 2007). At the end of the Paleozoic, several events of terrane accretion are recorded in South America (Pankhurst et al., 2006; Ramos, 2008; Calderón et al., 2016), between these the accretion of the Antarctic Peninsula terrane against Patagonia (Ramos, 2008; Calderón et al., 2016; Heredia et al., 2016), which indicate the final stages of Pangea assembly (320-250 Ma; Cawood and Buchan, 2007). Early Mesozoic tecto-magmatic events associated with continental breakup, are recorded along its SW margin (Bruhn et al., 1978; Pankhurst et al., 2000; Riley et al., 2001; Calderón et al., 2016; González et al., 2016), related to extensional movements that started to separate the Antarctic Peninsula from southern Patagonia.

Early Mesozoic paleogeographic reconstructions suggest that the Antarctic Peninsula was located in a very close position, or even attached, to SW Patagonia (Harrison et al., 1979; Miller et al., 1987; Lawver et al., 1992, 1998; Jokat et al., 2003; Hervé et al., 2006; König and Jokat, 2006; Ghidella et al., 2007; Heredia et al., 2016). However, these models still differ in the exact paleo-latitudinal position of the Antarctic Peninsula along the Pacific margin during the Triassic or older times. Some hypothesis suggests that the northern margin of Antarctic Peninsula was located nearby Golfo de Penas (Fig. 2; Lawver et al., 1998; Hervé and Fanning, 2003; König and Jokat, 2006) or farther north, close to the $39^{\circ} \mathrm{S}$, according to Heredia et al. (2016), while other reconstructions propose that the peninsula was situated either east of Patagonia or in continuity towards the south (Suárez, 1976;
Miller, 2007).

Plate reconstructions from aeromagnetic data establish a southward drifting of the Antarctic Peninsula during the Jurassic (Jokat et al., 2003; König and Jokat, 2006), synchronous with rifting and oceanic floor spreading in the Rocas Verdes basin in the backarc region of Patagonia (Dalziel, 1981; Calderón et al., 2007a).

\subsection{Late Paleozoic-early Mesozoic metamorphic units from southernmost} South America and Antarctic Peninsula

These units include several lower Paleozoic-Mesozoic blocks that formed the SW edge of Gondwana including possibly exotic terranes (Thomson and Hervé, 2002; Millar et al., 2002; Hervé et al., 2003, 2007; 2008; Calderón et al., 2016).

\subsubsection{Southern Patagonian Andes}

Metamorphic rocks cropping out in the Southern Patagonian Andes (Fig. 3) can be divided into (1) the EAMC (Eastern Andes Metamorphic Complex) along the eastern flank of the Patagonian Batholith, (2) the coastal accretionary complexes in the Pacific archipelago, and to a lesser extent (3) the ophiolitic complexes of the Rocas Verdes basin.

(1) The EAMC crops out along the inner core of the South Patagonian Andes (Hervé et al., 2008), including several units that compose the thick-skinned basement domain towards the east (Ghiglione et al., 2009). The Bahía de la Lancha and Río Lácteo formations, defined in Argentinean territory (see Giacosa and Márquez, 2002) were included by Hervé et al. (2008) in this vast metamorphic unit. The EAMC mainly consists in turbiditic sequences with occasional limestone bodies and metabasalt and their metamorphic 


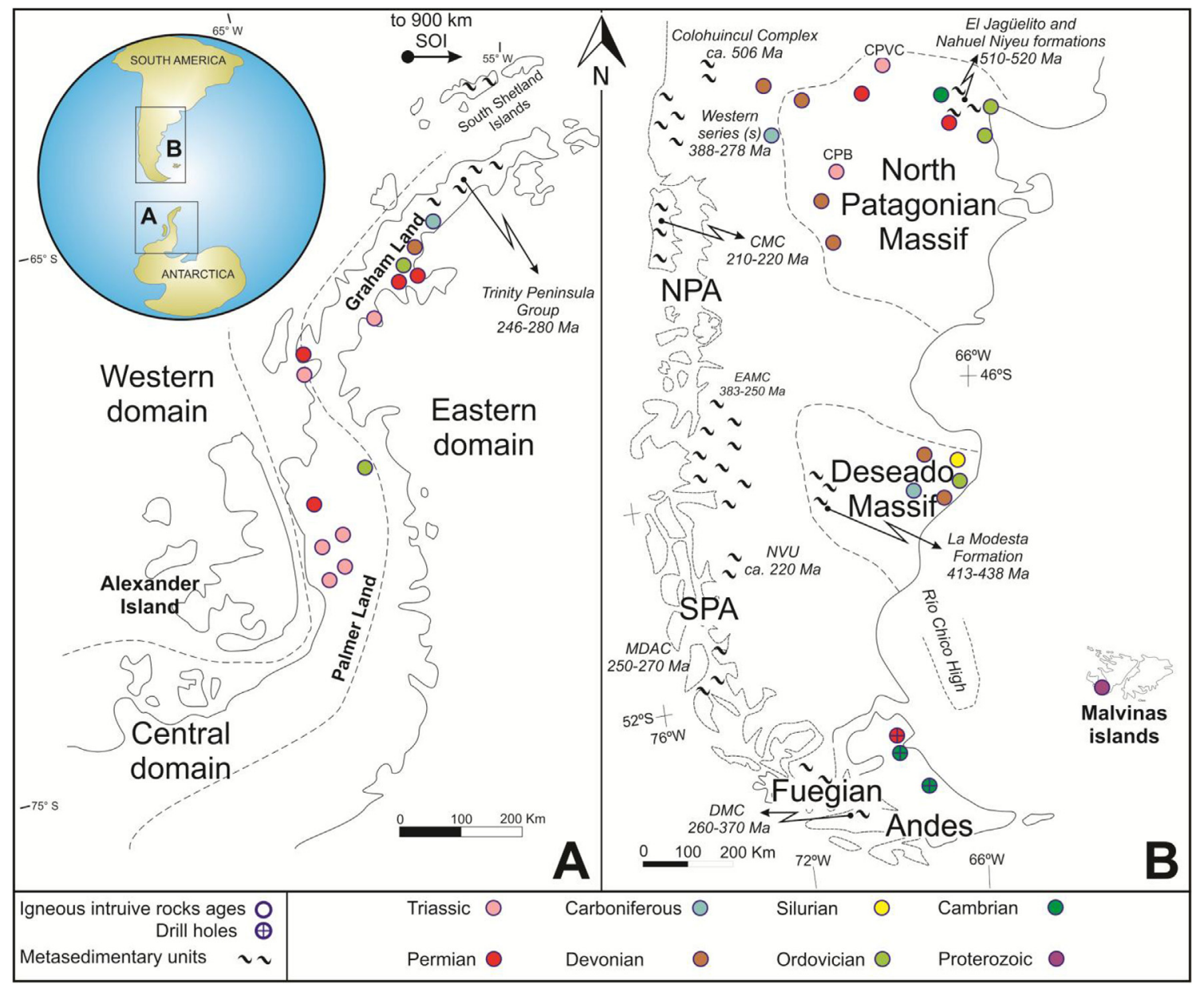

Fig. 3. Pre-Jurassic representative ages from Patagonia and Antarctic Peninsula. CMC: Chonos Metamorphic Complex; CPB: Central Patagonian Batholith; CPVC: Curaco Plutonic-Volcanic Complex. DMC: Darwin Metamorphic Complex; EAMC: Eastern Andes Metamorphic Complex; MDAC: Madre de Dios Accretionary Complex; NPA: North Patagonian Andes. NVM: Nunatak Viedma Metamorphites. SOI: South Orkney Islands. SPA: Southern Patagonian Andes. Patagonian ages are from Saini-Eidukat et al. (2004), Pankhurst et al. (2006), Zaffarana et al. (2014) and Greco et al. (2017) in the North Patagonian Massif; Pankhurst et al. (2003, 2006), Moreira et al. (2013) and Permuy Vidal et al. (2014) in the Deseado Massif; Cingolani and Varela (1976) and Jacobs et al. (1999) at Malvinas Islands; Hervé and Fanning (2001), Varela et al. (2005), Pankhurst et al. (2006), Hervé et al. (2016) and Serra-Varela et al. (2016) in the Northern Patagonian Andes and North Patagonian Chilean coast; Hervé et al. (2003) in the Southern Patagonian Andes; Sölner et al. (2000), Barbeau et al. (2009b), Calderón et al. (2010), Hervé et al. (2010a,b) and Castillo et al. (2017) in the Fuegian Andes. Antarctic Peninsula's ages are from Pankhurst (1982), Willan et al. (1994), Millar et al. (2002), and Riley et al. (2012).

equivalents in greenschist facies (Hervé et al., 2008). Sedimentary protoliths were deposited either in a passive margin environment (Augustsson and Bahlburg, 2003a, 2003b; 2008; Lacassie, 2003) or in a trench-forearc setting (Permuy Vidal et al., 2014; Calderón et al., 2016) during the Late Devonian-early Carboniferous (Augustsson et al., 2006) and metamorphosed previous to the Permian (Thomson and Hervé, 2002). Giacosa et al. (2012a), propose that the Bahía de la Lancha Formation was deformed during the late Paleozoic Gondwanide orogeny. Additionally, the western belt of the EAMC exhibits Late Permian-Early Triassic ages (Hervé et al., 2003; Augustsson et al., 2006), however its deformation and metamorphism age is still unknown. High-grade metamorphic rocks and migmatites located on the western border of the EAMC resulted fron the emplacement of Late Jurassic granitoids of the South Patagonian Batholith (Hervé et al., 2007; Calderón et al., 2007b).

(2) The Coastal accretionary-subduction complexes (Fig. 3) include (see Hervé et al., 2008; Calderón et al., 2016) the CMC (Chonos Metamorphic Complex), the MDAC (Madre de Dios Accretionary Complex) and the DAMC (Diego de Almagro Metamorphic Complex).

The CMC from the Chonos Archipelago is composed of metaturbidites and metabasites and meta-cherts in minor quantities (Hervé et al., 2008). The protolith was deposited during the Late Triassic (Fang et al., 1998; Hervé and Fanning, 2001) and subsequently affected by metamorphism and deformation during Late Triassic-Early Jurassic times, possibly related to the Chonide deformational event (Hervé et al., 2006, 2008). The high-pressure/low-temperature metamorphism is typical of accretionary prisms (Willner et al., 2000; Ramírez-Sánchez et al., 2005).

The MDAC includes three lithostratigraphic units known as: (i) the Tarlton limestone, composed by a massive pelagic limestone body deposited during the late Carboniferous-early Permian, (ii) the Denaro Complex represented by pillow basalts and radiolarian cherts, and (iii) the Duque de York Complex composed by turbiditic successions unconformably deposited over the Tarlton limestone and Denaro Complex (Forsythe and Mpodozis, 1979, 1983). The lower-middle Permian Duque de York Complex (Faundéz et al., 2002) experienced low-grade metamorphic conditions during the Early Jurassic, possibly related to an accretionary event (Thomson and Hervé, 2002). The Denaro and Tarlton complexes have generally been interpreted as oceanic exotic terranes (Faundéz et al., 2002; Rapalini et al., 2001).

The DAMC corresponds to the assemblage of two metamorphic units tectonically juxtaposed by the Puerto shear zone: the Almagro HP-LT 

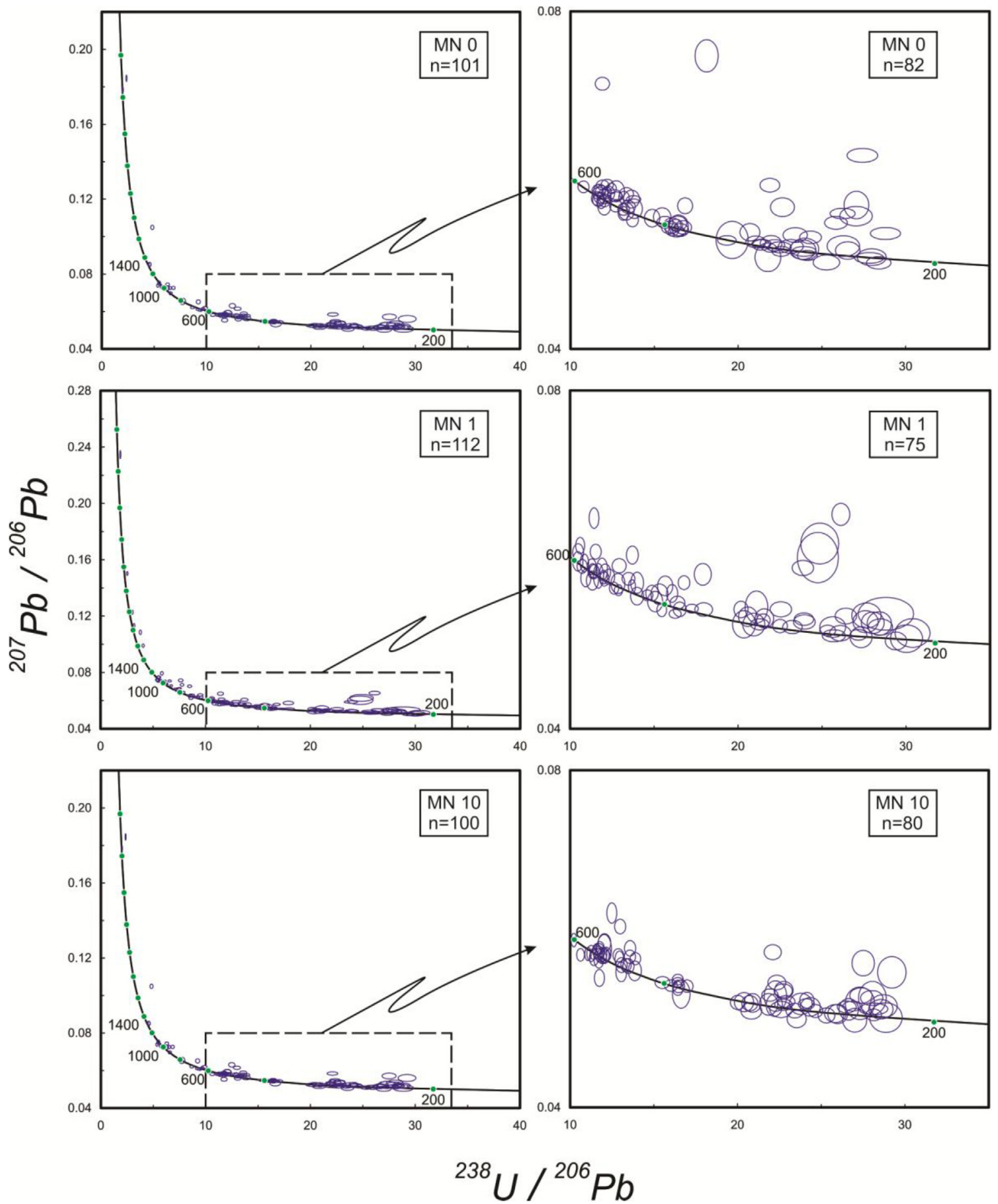

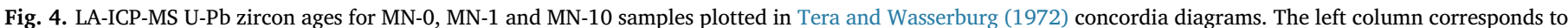
the entire spectrum of ages while the right column shows principally Paleozoic ages.

Complex composed by metamafic volcanic rocks with scarce metasedimentary rocks and the Lazaro Unit with seafloor-derived metamafic and metasedimentary rocks (Angiboust et al., 2017). The protolith of these high-pressure rocks have been deposited in the Late Jurassic and metamorphosed as part of an accretionary wedge that was active during the Cretaceous (Hervé and Fanning, 2003; Hyppolito et al., 2016; Angiboust et al., 2017, 2018).

(3) Ophiolitic complexes of the Rocas Verdes basin consist of sequences of massive and layered gabbros, sheeted dykes and basalts with oceanic affinity, whereas ultramafic rocks are absent (Stern and De
Witt, 2003; Calderón et al., 2007a). From north to south they are the Sarmiento Complex in the Southern Patagonian Andes and the Capitán Aracena and Tortuga complexes in the Fuegian range (Stern and De Witt, 2003; Calderón et al., 2013). These rocks were emplaced during the Late Jurassic-Early Cretaceous in a rift to backarc basin (Calderón et al., 2007a,b). The subsequent basin closure and obduction occurred during the Cenomanian-Coniacian (Calderón et al., 2007a, 2012; Klepeis et al., 2010), producing a major advance of the orogenic front and a wedge-top setting for the adjacent Austral-Magallanes basin depocenter (Fosdick et al., 2001; Likerman et al., 2013; Ghiglione et al., 2014, 2016). 


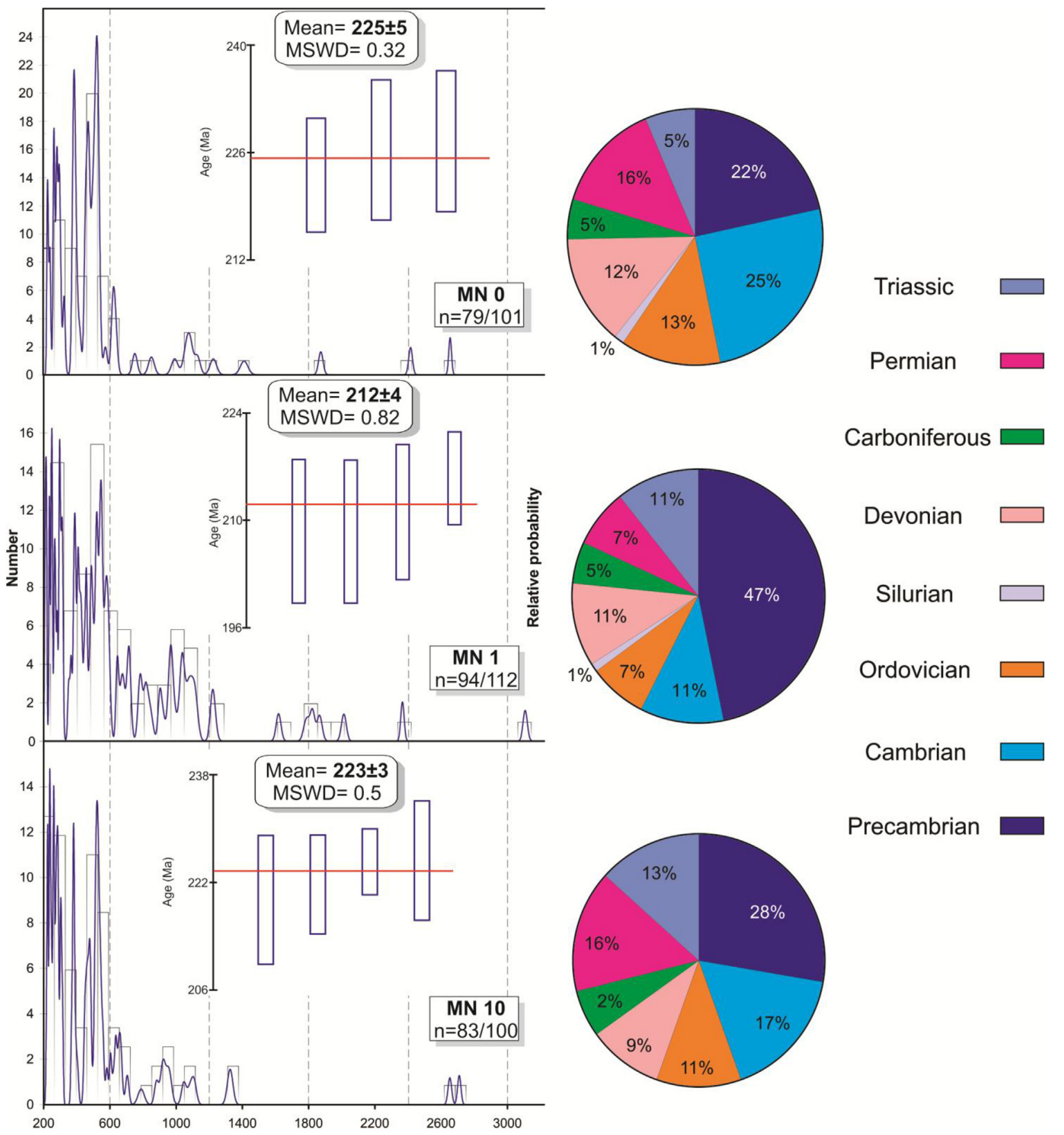

Fig. 5. The left column corresponds to the frequency histograms and relative probability plots of U-Pb detrital zircon ages (LA-ICP-MS). The inset shows weighted average age plots of the youngest cluster overlapping at $1 \sigma$. Weighted mean age is interpreted as the maximum depositional age. Pie-chart with the distribution of the zircon detrital ages for each sample is represented on the right column.

\subsubsection{Tierra del Fuego}

Metamorphic rocks of the Cordillera Darwin and extra-Andean region are known as Cordillera Darwin Metamorphic Complex and Tierra del Fuego Igneous and Metamorphic Complex (Fig. 3), respectively. At Cordillera Darwin the clastic protolith of the metasedimentary units were deposited in the Paleozoic (Hervé et al., 1981a, 2010b; Barbeau et al., 2009b) and their detrital zircon age spectra are comparable with those of the EAMC (Barbeau et al., 2009b; Hervé et al., 2010b). These metamorphic rocks are unconformably overlain by Jurassic volcaniclastic rocks, and the whole succession has been strongly deformed and metamorphosed in the Cretaceous by the Andean Orogeny (Hervé et al., 2010b; Maloney et al., 2011). The extra-Andean region of Tierra del
Fuego is characterized by Cretaceous-Cenozoic sedimentary rocks of the Austral-Magallanes basin (e.g. Ghiglione et al., 2010). Underlying foliated plutonic rocks (orthogneisses) and migmatitic gneisses were detected in boreholes. These rocks have Cambrian crystallization ages and are affected by a late Permian magmatic-anatectic event (Sölner et al., 2000; Calderón et al., 2010; Hervé et al., 2010a; Castillo et al., 2017).

\subsubsection{Antarctic Peninsula}

Basement rocks from the Antarctic Peninsula at Graham Land and Palmer Land yield in situ ages ranging from Ordovician to Late Triassic (Fig. 3; Millar et al., 2002; Riley et al., 2012). 

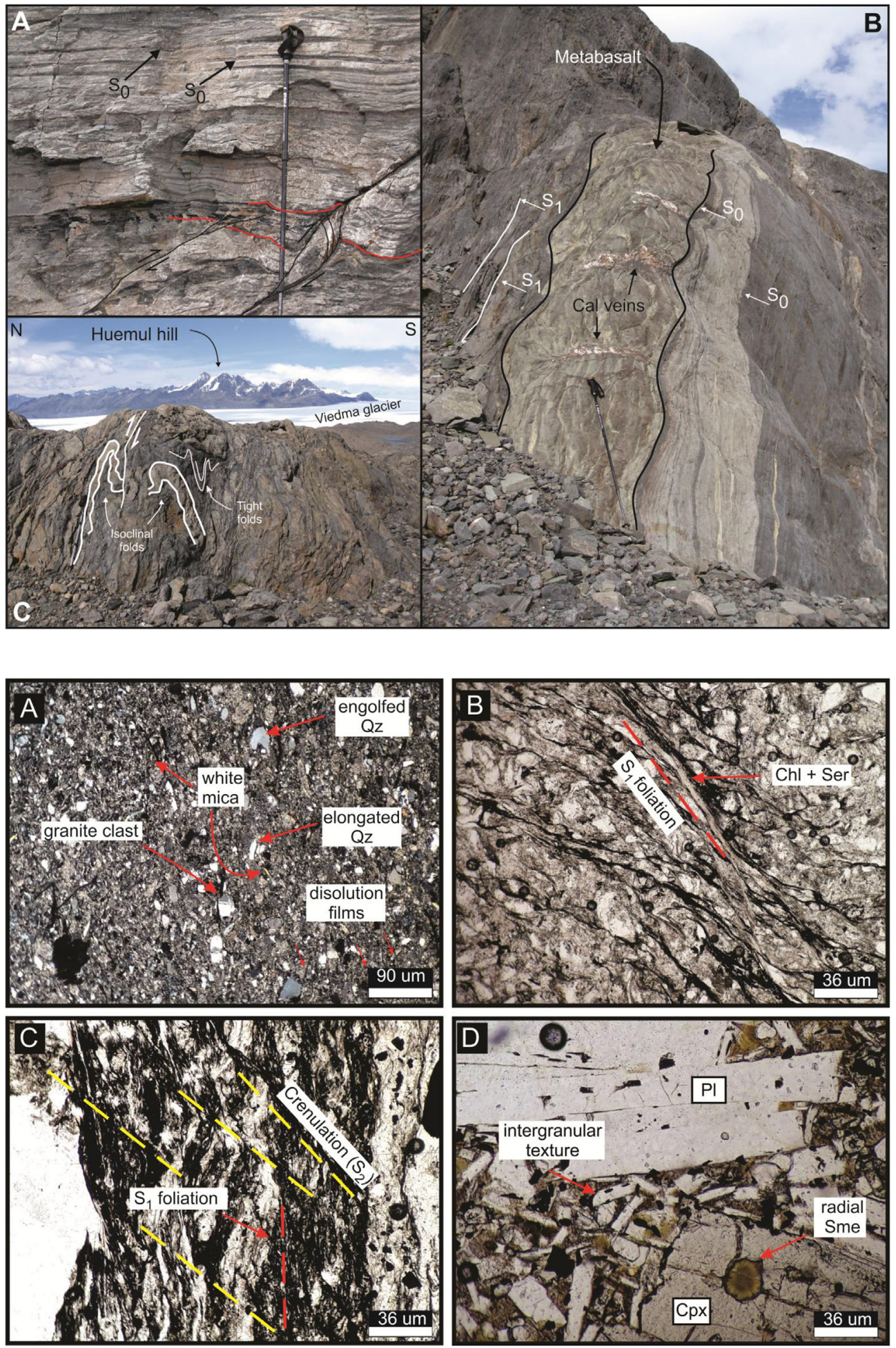

Fig. 6. Outcrops of the Nunatak Viedma locality showing lithological and structural features. A) Very low-grade metapsammites and metapelites with excellent preservation of bedding cut by a mid angle reverse fault. B) Metasedimentary rocks interbedded with metabasites with boudins development and calcite veins in the neck of the structure. C) Metapsammites and metapelites showing upright isoclinal and tight folds, and highangle reverse faults.
Fig. 7. Photomicrographs of metapsammites and metabasites from NVU. A) typical composition of the metapsammites. B) $S_{1}$ cleavage and associated growth of chlorite + sericite. C) $S_{1}$ cleavage affected by a crenulation cleavage $\left(S_{2}\right)$ developed in brittle conditions. D) Metabasite with porphyric texture exhibiting plagioclases + clinopyroxene phenocrysts within fine-grained groundmass composed by mafites, opaques, and plagioclase.
In this region, three geological domains separated by shear zones are recognized (Fig. 3; Vaughan and Storey, 2000; Ferraccioli et al., 2006; Burton-Johnson and Riley, 2015). The Permian-Upper Triassic to Lower Jurassic Central domain is composed by subduction-related granites, orthogneiss and migmatites cropping out in Palmer Land area (Wever et al., 1994; Millar et al., 2002; Riley et al., 2012). The Eastern domain includes the Permian to Triassic TPG (Trinity Peninsula Group), whose age is constrained by U-Pb dating in detrital zircons and stratigraphic relationships (Carvalho et al., 2005; Barbeau et al., 2009a; Castillo et al., 2016). This group has been divided into the Hope Bay,
View Point and Legoupil formations composed of metaturbidites and metapillow lavas deposited in a forearc basin (Hyden and Tanner, 1981). Unconformably overlain on the TPG, Heredia et al. (2016) redefine the uppermost Düse Bay Formation described by Del Valle et al. (2007) as a synorogenic succession deposited in a retroarc foreland basin and related to the Tabarin Permian-Triassic orogeny. To the northeast of the Antarctic Peninsula, the South Orkney Island (Fig. 3) at the southern limb of the Scotia Range exhibits outcrops of the Greywacke-shale Formation interpreted as a possible Triassic equivalent of the TPG (Dalziel, 1982; Trouw et al., 1997). 


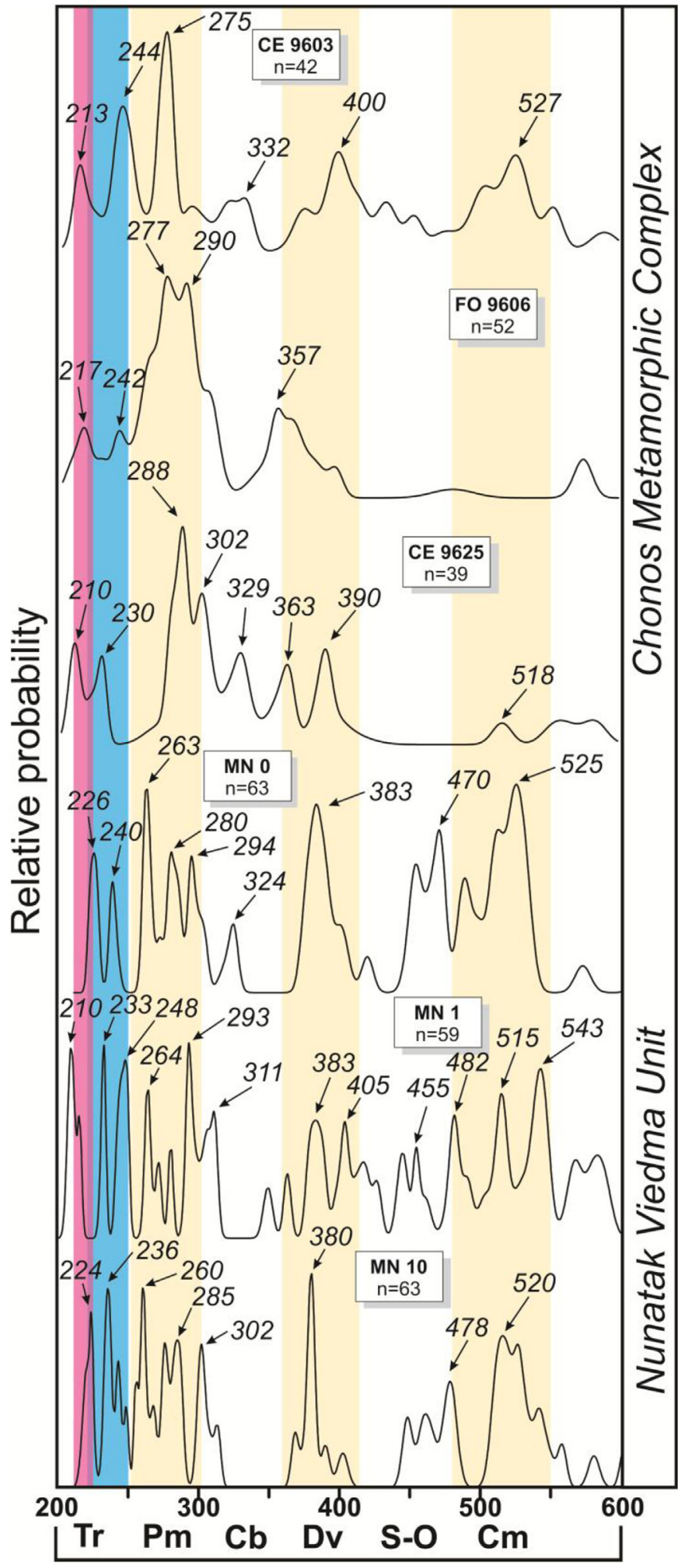

Fig. 8. Paleozoic-lower Mesozoic relative probability distribution from Chonos Metamorphic Complex (CE9603, FO9606 and CE9625 samples from Hervé and Fanning, 2001) and Viedma Nunatak Unit (MNO, MN10 and MN1 samples from this study). NVU shows prominent lower Paleozoic peaks, which are not represented in the CMC, while the Permian-Triassic peaks are represented in both units. Violet and sky-blue lines depict the MDA from CMC and NVU, respectively. (For interpretation of the references to colour in this figure legend, the reader is referred to the Web version of this article.)

\section{Metamorphic rocks of the Nunatak Viedma unit}

\subsection{Field and petrographic lithological characterization}

The rocky out crop of the Nunatak Viedma is modeled by glaciary processes and presents no evidence of volcanic activity. The rocks correspond mainly to metapsammites, metapelites and scattered interbedded metabasites (Fig. 6). The metapsammites are gray, present scarce clasts of both felsic volcanic rocks and granites and pumice wisps with tube vesicle texture. In all samples, grains of quartz, white mica, and plagioclase are dominant (Fig. 7A) with scarce K-feldspar and accessories like zircon, tourmaline, apatite, and titanite. The minerals are distributed in the quartz-plagioclase and quartz-white mica domains, which are interpreted as remnants of a prior sedimentary lamination $\left(\mathrm{S}_{0}\right)$. Sometimes the mechanically reoriented and kinked detrital mica together with dissolution films define a diagenetic foliation (sensu Passchier and Trouw, 2005). The metamorphic mineral assemblage is composed of quartz, chlorite, white mica and carbonate (Fig. 7B). The fine bands formed by intergrowths of white mica and chlorite define the $\mathrm{S}_{1}$ foliation (Fig. 7B and C). Chlorite locally replaces white mica and also is present as porphyroblasts. The mica-rich domains, consisting of white mica and chlorite, are affected by a poorly developed crenulation cleavage $\left(\mathrm{S}_{2}\right.$; Fig. $\left.7 \mathrm{C}\right)$. By last, the rocks are crosscut by veinlets of carbonate and quartz.

The metabasites preserve amygdaloidal and porphyritic primary textures (Fig. 7D). Primary igneous phases are composed of plagioclase, clinopyroxene, pseudomorphs of olivine and opaques (Fig. 7D). Metamorphic mineral assemblages vary between samples; the most common are: i) chlorite, smectite, zeolite and carbonates (Fig. 7D); ii) chlorite, pumpellyite (?); iii) actinolite, chlorite; and iv) smectite, quartz, and carbonate. These minerals occur in amygdules and micro-veinlets, or as the alteration product of plagioclase.

\subsection{Estimations of metamorphic P-T conditions}

Deformation processes associated to micro-structures, identification of metamorphic mineral assemblages and their comparison with petrogenetic grids for metabasites (Schiffman and Day, 1999) and with typical metamorphic mineral assemblage for metapelites (Bucher and Grapes, 2011), indicate that metamorphism during deformation and developments of $S_{1}$ foliation progressed in very low to low-grade conditions.

The textural equilibriums among white mica + chlorite + quartz + carbonate in metapsammites indicate a sub-greenschist facies of metamorphism (chlorite zone), with estimated temperatures at $200-300{ }^{\circ} \mathrm{C}$ and pressures between 1.5 and $3.0 \mathrm{kbar}$.

The mineral assemblage identified in the metabasites indicate a formation temperature of $180-230{ }^{\circ} \mathrm{C}$ and variable pressures between 1 and $3 \mathrm{kbar}$ to chlorite + pumpellyite mineral association, while the appearance of actinolite could be point out temperatures greater than $300{ }^{\circ} \mathrm{C}$. These physical conditions correspond to the transition between sub-greenschist and greenschist facies.

\section{U-PB zircon detrital ages in metasedimentary rocks}

\subsection{Analytical techniques}

Three samples were taken in site $49^{\circ} 25^{\prime} 50^{\prime \prime} \mathrm{S} / 73^{\circ} 18^{\prime} 30^{\prime \prime} \mathrm{W}$ (Fig. 1) to analyze detrital zircons by U-Pb method in the Washington State University Laboratory, following the methodology described in Chang et al. (2006). Approximately three hundred zircon grains were separated from a total of $5 \mathrm{~kg}$ of three metapsammites (samples MNO, MN1 and MN10). Heavy mineral fractions were concentrated and separated into 100,150 and $250 \mathrm{~mm}$ size fractions by standard crushing and panning. Zircon fractions of roughly 400 grains were handpicked in alcohol under a binocular microscope for geochronology analysis. Zircons of 


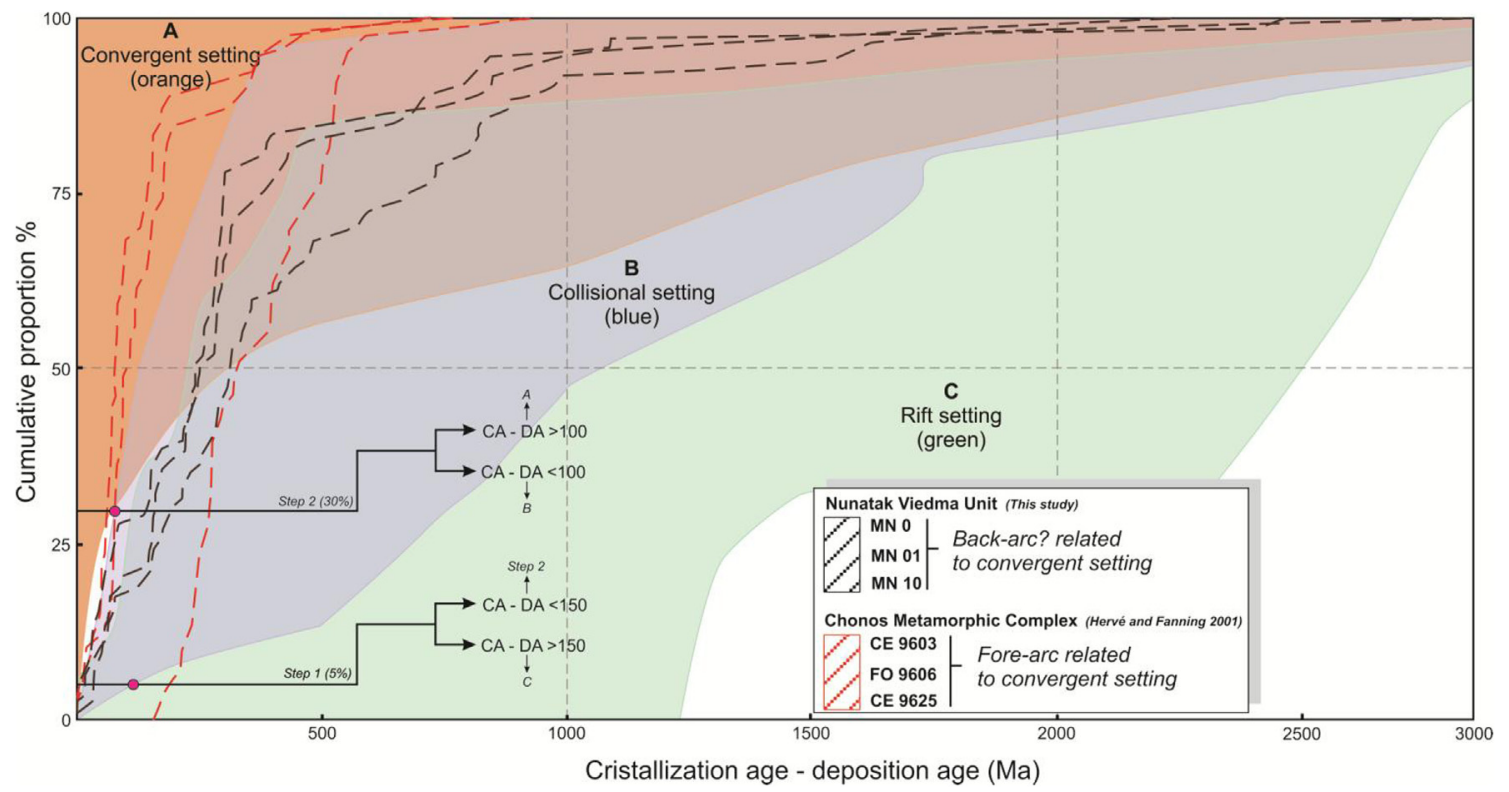

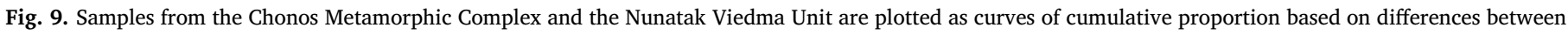

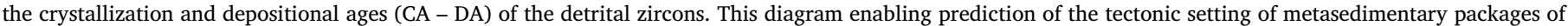

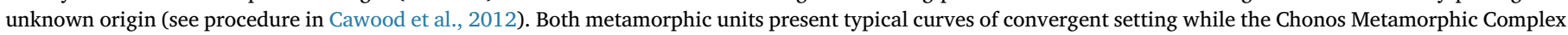

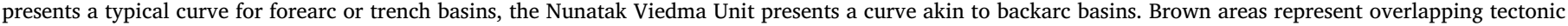
fields. (For interpretation of the references to colour in this figure legend, the reader is referred to the Web version of this article.)

unknown ages and standards were handpicked under the microscope and mounted in a 1-inch diameter epoxy puck and slightly ground and polished to expose the surface and keep as much material as possible for laser ablation analyses. After cathodoluminescence imaging, the LAICP-MS U-Pb analyses were conducted using a New Wave Nd: YAG UV 213-nm laser coupled to a Thermo Finnigan Element 2 single collector, double-focusing, magnetic sector ICP-MS. Laser spot size and repetition rate were $30 \mu \mathrm{m}$ and $10 \mathrm{~Hz}$, respectively. He and Ar carrier gases delivered the sample aerosol to the plasma. Each analysis consists of a short blank analysis followed by 250 sweeps through masses 202, 204, $206,207,208,232,235$, and 238, taking approximately $30 \mathrm{~s}$. Timeindependent fractionation was corrected by normalizing $\mathrm{U} / \mathrm{Pb}$ and $\mathrm{Pb} /$ $\mathrm{Pb}$ ratios of the unknowns to the zircon standards (Chang et al., 2006). $\mathrm{U}$ and Th concentration were monitored by comparing to NIST 610 trace element glass. Two zircon standards were used: Plesovice, with an age of $338 \mathrm{Ma}$ (Sláma et al., 2008) and FC-1, with an age of $1099 \mathrm{Ma}$ (Paces and Miller, 1993). Uranium-lead ages and plots were calculated using Isoplot (Ludwig, 2003). Analyses were corrected assuming concordance and applying a common $\mathrm{Pb}$ correction using the $207 \mathrm{~Pb}$ method (Williams, 1998).

The analytical data with concordant ages are reported in the Supplementary Data, including uncertainties at the $1 \sigma$ level, and measurement errors. Best ages were chosen based on the precision of the isotopic systems, thus ${ }^{206} \mathrm{~Pb} /{ }^{238} \mathrm{U}$ ages were selected for zircons younger than $1200 \mathrm{Ma}$ and ${ }^{207} \mathrm{~Pb} /{ }^{206} \mathrm{~Pb}$ ages for older ones (Gehrels et al., 2008). In a first step, all ages were plotted in the Tera and Wasserburg (1972) Concordia diagram (Fig. 4). Afterward, a filtering was applied to assess discordant ages, which can be quantified using the ratio between ${ }^{206} \mathrm{~Pb} /{ }^{238} \mathrm{U}$ and ${ }^{207} \mathrm{~Pb} /{ }^{206} \mathrm{~Pb}$ ages (Fig. 4; Wetherill, 1956; Spencer et al., 2016). The resulting percentage of "discordance" was set at $20 \%$ as commonly used for detrital zircons (e.g. Nelson and Gehrels, 2007; Naipauer et al., 2010; among many others).

\subsection{Estimation of maximum depositional age}

Obtaining the MDA (maximum depositional age) of a geological unit is one of the most widely used applications of detrital zircon geochronology and can be calculated from different methods
(Dickinson and Gehrels, 2009). The age of the youngest zircon from a data set gives some insights, but uncertainty on the precision of a single age is still large since it does not allow a statistical or modal test (Dickinson and Gehrels, 2009; Gehrels, 2014). Other methodologies provide more conservative estimations and have turned out coherent in units with biostratigraphic control, as the weighted mean age of a cluster composed by the three (or more) youngest zircons whose $\sigma$ errors overlap (Dickinson and Gehrels, 2009). We applied this methodology to calculate a conservative MDA from each sample, and the average of these three ages was assumed as the MDA of the unit.

\subsection{Detrital zircon features and $U-P b$ data}

In all the analyzed samples the pattern of detrital ages, external morphology of the detrital zircon grains and $\mathrm{Th} / \mathrm{U}$ ratio are very similar. For this reason, they will be described as a unique set. Fig. 5 shows the distribution of detrital zircon ages for each sample and the probability plots and associated maximum depositional age estimations.

About one hundred zircon grains were analyzed from each sample but only 79 of 101 (MN0), 94 of 112 (MN1) and 83 of 100 (MN10) zircons grains with discordance values $<20 \%$ endured filtering. Concordant zircon ages define a complex pattern of detrital ages that range from the Archean to the Late Triassic (Fig. 5).

Detrital zircon grains are $50-260 \mu \mathrm{m}$ in length (median length is $114 \mu \mathrm{m}$ ) and their external morphology exhibits different classes (according to Gärtner et al., 2013), concentrated in stubby- and stalkytypes. The $\mathrm{Th} / \mathrm{U}$ ratios show values between 0.05 and 2.47 ; in all samples the $\mathrm{Th} / \mathrm{U}$ is at least $87 \%$ greater than 0.2 , indicating an igneous origin for most of them.

The age distribution of detrital zircon grains include representative Paleozoic-early Mesozoic (65\%), Proterozoic (34\%) and isolated Archean ages (1\%; Fig. 5). The peaks of detrital ages define five main groups in the Paleozoic-Mesozoic: Early Cambrian ( $\sim 520 \mathrm{Ma})$, EarlyMiddle Ordovician ( $\sim 480-460 \mathrm{Ma})$, Late Devonian ( $\sim 380 \mathrm{Ma})$, Permian ( $\sim 290-260 \mathrm{Ma})$ and Triassic ( $\sim 235-225 \mathrm{Ma})$. Precambrian ages are concentrated in the Neoproterozoic around $\sim 1090 \mathrm{Ma}, \sim 960 \mathrm{Ma}$, and $\sim 630 \mathrm{Ma}$. MDAs are Late Triassic, at $225 \mathrm{Ma}$ for MN-0, $212 \mathrm{Ma}$ for 


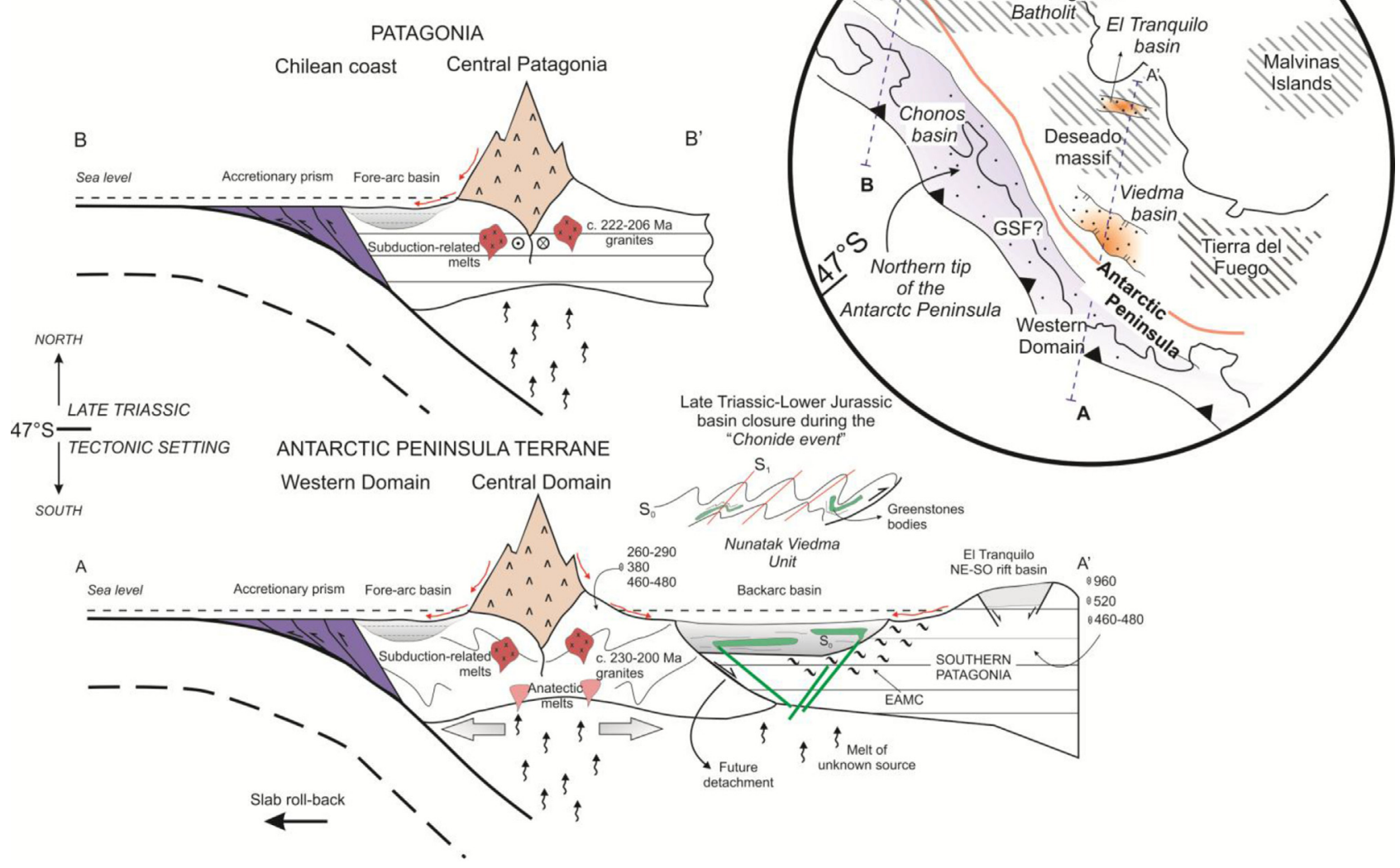

Fig. 10. Interpretation of the Late Triassic tectonic setting of the southwestern margin of Pangea and the paleogeographic implications on the Patagonia-Antarctic Peninsula connection. The A- $\mathrm{A}^{\prime}$ schematic profile exhibits the tectonic setting south of the $47^{\circ} \mathrm{S}$, and the developed of the Nunatak Viedma basin in a retroarc postion respect to the magmatic arc emplaced along Antarctic Peninsula. Subsequent closure of the basin ocurred during the Chonide deformation event. The B-B' schematic profile (based from Rapela et al., 1992; Zaffarana et al., 2014, 2017) show the tectonic setting north of the $47^{\circ}$ S. The red line in the paleogeographic reconstruction depicts the position of the magmatic arc (topographic barrier) emplaced along Antarctic Peninsula arc with continuation in Patagonia (Central Patagonian Batholith and farther north). EAMC: Eastern Andes Metamorphic Complex. GSF: Greywacke-Shale Formation. (For interpretation of the references to colour in this figure legend, the reader is referred to the Web version of this article.)

MN-1 and 223 Ma for MN-10 (Fig. 5), with errors within \pm 5 Ma.

\section{Discussion}

In a first approach, the metamorphic rocks of the Nunatak Viedma could be included as part of the EAMC on the basis of its geographical proximity and lithological similarities. However, the Late Triassic peak of U-Pb zircon detrital ages clearly differentiates a new tectonostratigraphic unit in the collage of pre-Andean metamorphic belts of the Southern Patagonian Andes. We propose to denominate these rocks as Nunatak Viedma Unit (NVU). Based on petrographic and geochronological data, the geological significance of the NVU and its possible correlations with other metamorphic complexes of the southwestern edge of Gondwana in the early Mesozoic, are discussed below.

\subsection{Provenance sources and paleogeographic implications}

In quartz-rich metapsammites, with a fine-grained terrigenous, probably turbiditic protolith, detrital zircon populations of Late Triassic, Paleozoic (Cambrian, Ordovician, Devonian, Permian), Neoproterozoic and isolated Archean ages were identified.

Archean and Proterozoic detrital zircon ages have been previously identified in metamorphic complexes located along the Patagonian Andes, for example in the EAMC (Hervé et al., 2003; Augustsson et al.,
2006). However, Patagonia as a primary (igneous) cratonic source of detrital zircons still remains under discussion, because of the lack of magmatic outcrops of that age. Precambrian primary source areas are located in South America north of Patagonia, Africa and East Antarctica (cf. Hervé et al., 2003; Augustsson et al., 2006), and we consider these primary sources areas to be located too far north and east to have reach the NVU basin directly. For this reason, Precambrian detrital ages identified within the Triassic NVU, can be more easily explained by recycling of the nearby EAMC and also from other Paleozoic igneousmetamorphic complexes with outcrops in surrounding areas, probably exposed at the time of NVU deposition.

Recent works consider the Malvinas Islands and southern Patagonia as a single continental block (Ramos et al., 2017; Schilling et al., 2017). From that perspective, Mesoproterozoic Grenvillian sources could correspond to granites and gneisses of the Cabo Belgrano Complex, which are cropping out in the Malvinas islands (Fig. 3b; Cingolani and Varela, 1976; Rex and Tanner, 1982; Thomas et al., 2000) and possibly in the neighboring Argentinean Atlantic platform (Wareham et al., 1998; Chemale Jr. et al., 2018).

On the other hand, Paleozoic and Mesozoic detrital zircons could potentially come from multiple sources (Fig. 3a and b). The early Cambrian zircon ages, related to the Pampean orogen in center and northwest Argentina and the Ross-Delamerian orogen in northern Patagonia (Ramos and Naipauer, 2014; González et al., 2018) and 


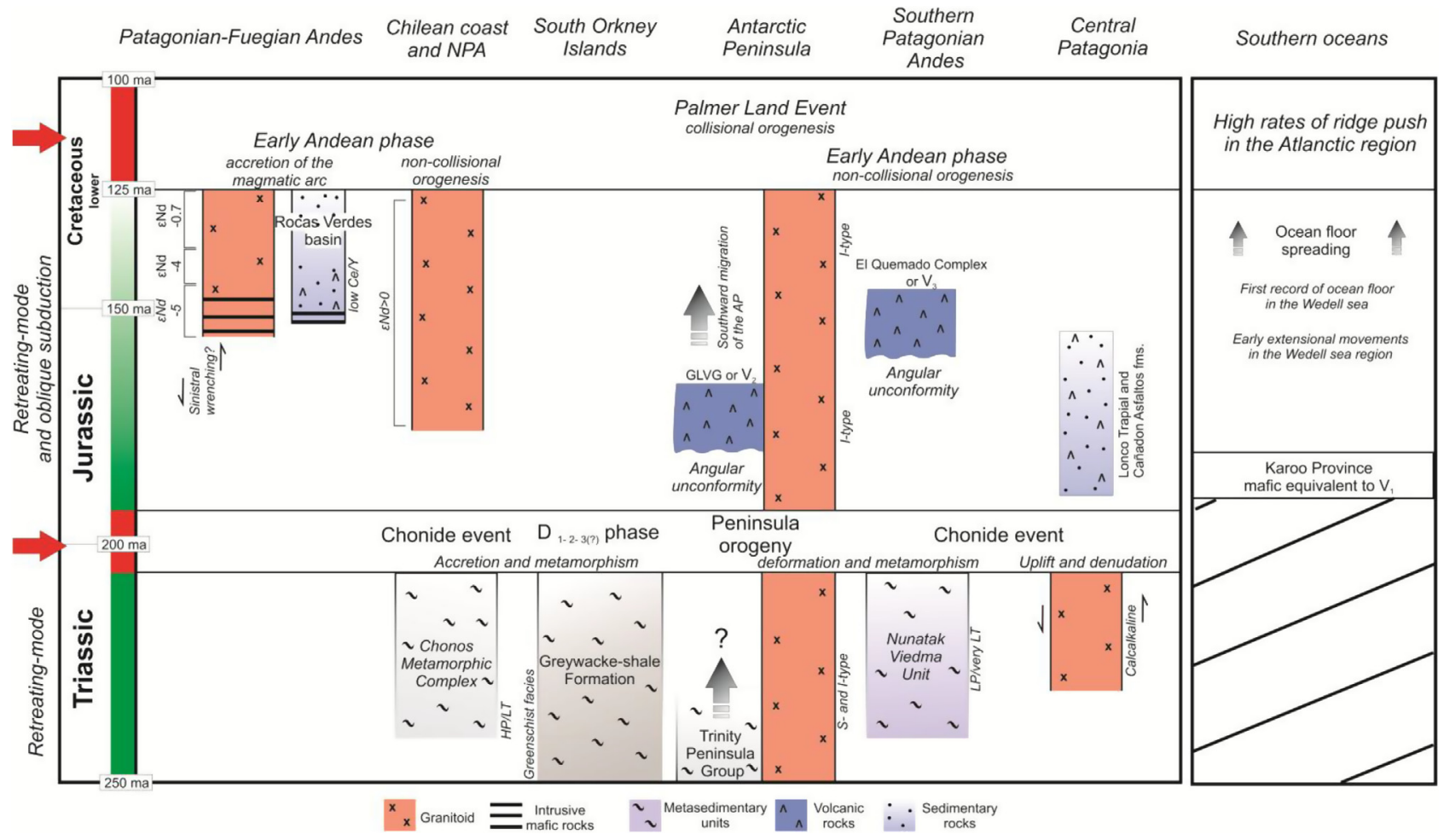

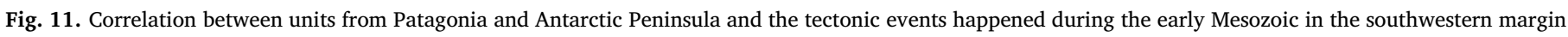

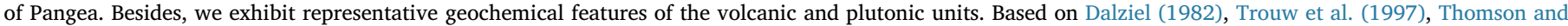

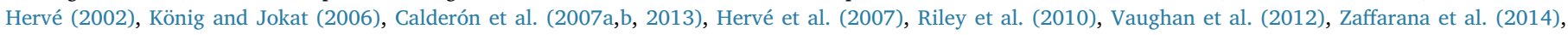
Echaurren et al. (2016), Ghiglione et al. (2016) and this study. V1, V2, and V3 represent episodes of Jurassic volcanism defined by Pankhurst et al. (2000).

Antarctic-Australia (Cawood and Buchan, 2007). In the North Patagonian Massif, the low-grade (Nahuel Niyeu and El Jaguielito formations) and high-grade (Mina Gonzalito Complex) metamorphic units and the Tardugno Granodiorite present Cambrian ages (Fig. 3b; Pankhurst et al., 2006; González et al., 2011; Rapalini et al., 2013; Greco et al., 2017). Cambrian gneisses and foliated plutonites, pertaining to the Tierra del Fuego Igneous and Metamorphic Complex, have been identified in exploratory boreholes of the Austral-Magallanes basin (Söllner et al., 2000; Hervé et al., 2010a). The crystallization age of these igneous rocks was calculated at around of $520 \mathrm{Ma}$ (Söllner et al., 2000; Pankhurst et al., 2003; Hervé et al., 2010a), it turns out to be highly coincident with early Cambrian peak presents in our samples.

Detrital ages grouped at $\sim 460-480$ Ma peaks could be sourced from Lower to Middle Ordovician granitoids of the Punta Sierra Plutonic Complex in the North Patagonian Massif (Fig. 3b; Pankhurst et al., 2006; González et al., 2008, 2014) and the Río Deseado Complex in the Deseado Massif (Loske et al., 1999; Pankhurst et al., 2003). Also, basement outcrops in Graham Land at the Antarctic Peninsula are composed of dioritic gneisses with Ordovician ages (Fig. 3a; Riley et al., 2012).

The Devonian peak could be associated with widely represented igneous rocks in the Northern Patagonian Andes (Varela et al., 2005; Pankhurst et al., 2006; Hervé et al., 2016) and in the western part of the North Patagonian Massif (Hervé et al., 2016). These ages are poorly represented in the Southern Andes, Antarctic Peninsula (Millar et al., 2002; Pankhurst et al., 2003) and in the Deseado Massif (Pankhurst et al., 2003). Devonian detrital ages are also common in the EAMC (Augustsson et al., 2006) and in metamorphic rocks from the western Deseado Massif (Permuy Vidal et al., 2014).

An important Permian-Triassic zircon population suggests erosion of post-Gondwanan igneous rocks and of a late Paleozoic-early Mesozoic magmatic arc active during sedimentation of the NVU. An alternative explanation to the Permian detrital ages could be the recycling from the western belt of the EAMC. Permian Igneous rocks $(\sim 280-250 \mathrm{Ma})$ has been identified in the North Patagonian Massif (Fig. 3b; Pankhurst et al., 2014), although plutonic samples of that age are scarce in southern Patagonia. Recently, new zircon U-Pb radiometric data obtained principally in the Antarctic Peninsula, but also some in Tierra del Fuego (Calderón et al., 2010; Hervé et al., 2010a; Millar et al., 2002; Castillo et al., 2017) demonstrates a widespread distributed Permian metamorphic-magmatic event. Castillo et al. (2016) studied Permian to Triassic metasedimentary rocks from the Pacific coast of SW Chile using isotope analyses in detrital zircon grains and they suggested the Permian subduction-related magmatic arc located in Patagonia and west Antarctic as an important source.

From a paleogeographic point of view, plutonic rocks (between 236 and $200 \mathrm{Ma}$ by Millar et al., 2002 and Riley et al., 2012) from the Antarctic Peninsula arc, located to the W and SW (Fig. 3a) were the closest possible source for Triassic detrital zircons (235-208 Ma) during sedimentation of the protolith of the NVU, taking into account the hypothesis that the Antarctic Peninsula was attached to Patagonia at that time (Fig. 2; Calderón et al., 2016; Castillo et al., 2016; Heredia et al., 2016).

In summary, U-Pb analysis in detrital zircons from the NVU show a wide distribution of ages with all Paleozoic to early Mesozoic periods very well represented, as well as an important Proterozoic component (Figs. 5 and 8). The diverse although equitable zircons distribution (Fig. 5) can only be explained by considering a multiplicity of sources for the Proterozoic-Paleozoic components, located in Patagonia and Antarctic Peninsula (Fig. 3a and b). We propose that the very well represented and particular Permian-Triassic group of ages (Figs. 5 and 8) was sourced from the active magmatic arc emplaced onto the Trinity Peninsula Group along Antarctic Peninsula. 


\subsection{Nature, age, and correlations of the Viedma basin}

If we consider the petrography, and particularly the detrital zircon age spectra (sensu Cawood et al., 2012) as an expression of the tectonic setting of the NVU protolith, i.e. the Viedma basin, their distribution indicate a basin flanked by an active Late Triassic magmatic arc (Fig. 9). In order to further define the nature of this basin and its position with respect to the recognized Triassic magmatic arcs is necessary to take into account the regional correlation with other contemporaneous metamorphic units.

Metamorphic belts with protoliths of Triassic age are rare in the Patagonian Andes, except by the CMC located in the present forearc about 300-400 km to the northwest of the NVU (Fig. 3). Detrital zircons ages (Hervé and Fanning, 2001) and fossils record (Fang et al., 1998), constraint the sedimentation age in a Late Triassic basin, within an environment of accretionary wedge (Hervé et al., 1981b; Hervé, 1988), here onwards called the "Chonos basin".

The distribution pattern of detrital ages of the CMC and NVU shows that both basins were mainly fed by Permo-Triassic sources, although the NVU exhibits particular Neoproterozoic, Cambrian, and Ordovician detrital ages probably sourced from the Patagonian massifs (see section 5.1.). Trench or forearc basins such as the Chonos basin, present a large population of detrital ages close to the sedimentation age without large proportions of older zircon grains, while basins in a retroarc position present an input of older detrital sources from the adjacent basement outcrops (Fig. 9; Cawood et al., 2012). Given the broad range of detrital ages found in the NVU, it seems that the Viedma basin was probably a retroarc position (Fig. 10).

Conscious of the difficulty that represent to infer paleogeography from provenance data due to the complexity of the drainage systems and their catchment areas (Cawood et al., 2003), the Triassic volcanic arc emplaced along Antarctic Peninsula, and possibly with continuation in Central Patagonia (i.e. Central Patagonian Batholith and Curaco Plutonic-Volcanic Complex, with ages between 222 and 206 Ma; Rapela et al., 1992; Saini Eidukat et al., 2004; Zaffarana et al., 2014), could have played the role of topographic barrier between both compared basins. In this way, the Viedma basin caught Neoproterozoic, Cambrian and Ordovician zircon grains sourced from extra-andean Patagonian basement highs sources located to the east, while Chonos basin was fed by the flanking Triassic arc and the underneath host rock.

\subsection{Early Mesozoic dynamics of the subduction system}

Accretionary orogens were traditionally classified according with their surrounding subduction style, considering and linking mainly slab dip angle, strain class in the upper plate and trench migration (Uyeda and Kanamori, 1979; Jarrard, 1986; Stern, 2002; Heuret et al., 2007; Ramos, 2010). In this context, two end-members have been identified: advancing and retreating orogens (sensu Cawood et al., 2009). In the second case, the dynamics of the orogen (see more in Collins, 2002a) induce lithospheric extension and the development of backarc basins (Collins, 2002b; Cawood et al., 2009). The early Mesozoic arc-backarc system established along of the west margin of Patagonia and Antarctic Peninsula shows close relationship with this kind of accretionary orogen undergoing extension.

Early Mesozoic orthogneisses and foliated granites emplaced along Antarctic Peninsula (mainly in the Central Domain) were interpreted as products derived from the subduction zone but during a regime of lithospheric extension (Wever et al., 1994). Likewise, the Late Triassic in Patagonia and along of the western margin from South America was characterized by extension during ongoing subduction (Giambiagi et al., 2009; Giacosa et al., 2010; Spikings et al., 2016; González et al., 2017). Its simultaneity with the development of the Viedma basin supports our hypothesis of an extensional aperture of the Viedma basin during the Late Triassic (Fig. 10).

Folded basement rocks around Paso del Viento that we assign to the
NVU on the basis of lithological affinity (Fig. 1) and are overlain in angular unconformity by Upper Jurassic volcanic rocks from El Quemado Complex (153-162 Ma by Pankhurst et al., 2000). Such stratigraphic relations can indirectly constraint the Viedma basin closure, deformation, and metamorphism, between the Late Triassic and the Middle Jurassic (Fig. 11). Regionally, this deformational event can be related to the Late Triassic (?)-Early Jurassic Chonide accretionary event (Fig. 11; Thomson and Hervé, 2002; Hervé et al., 2008), which affected the CMC and the Central Patagonian region (Fig. 11; Zaffarana et al., 2014), and was synchronous with the Peninsula orogeny in the Antarctic Peninsula (Fig. 11; Vaughan and Livermore, 2005; Hervé et al., 2006). Overall our tectonic reconstruction marks a tectonic mode switching from Late Triassic extension (or transtension?) to Early Jurassic contraction (Fig. 11).

In southernmost Patagonia, towards the latest Jurassic new evidences of extension and establishment of a backarc setting are registered in the Rocas Verdes basin (Fig. 11; cf. Calderón et al., 2007a), which located southwest from NVU. This means an oceanward migration of the arc-backarc system after the deformation (closure) of the NVU. Whereas at Central Patagonia also registers, from the Late Triassic to Early Cretaceous, a westward migration of the arc magmatism, in fact, this arc magmatism develops during a period of upper plate extension (Echaurren et al., 2016). This pattern of arc-backarc system younger outboard associated to extension, disrupted by short-lived deformation events, were features identified as typical from retreating orogens (Collins, 2002a, 2002b; Cawood et al., 2009).

Even though the dynamics of the Mesozoic orogenic system could be reflecting a retreating-mode, in southernmost Patagonia, its evolution is quite complex and was influenced by the connection with the Antarctic Peninsula (Hervé and Fanning, 2003; Calderón et al., 2007a). The Jurassic arc magmatism emplaced along the Patagonia-Antarctic Peninsula (Hervé et al., 2007; Echaurren et al., 2016; Riley et al., 2016), was synchronous with the Middle-Late Jurassic extensional-transtensional movements that started to separate the Antarctic Peninsula composite terrane (magmatic arc and forearc setting) from Patagonia (König and Jokat, 2006). Indeed, the lithospheric extension finally resulted in the appearance of oceanic floor in the Weddell Sea at $\sim 160$ $147 \mathrm{Ma}$ (Fig. 11; see discussion in Ghidella et al., 2007) and the partial separation between both blocks, concomitant with the development of the Rocas Verdes basin. Finally, towards Cretaceous times, the rocks of the southernmost Chilean margin were involved in the process of subduction (Hervé and Fanning, 2003; Angiboust et al., 2018) revealing that Antarctic Peninsula was located farther south from Patagonia (Hervé and Fanning, 2003).

\section{Conclusions}

We propose a new lithostratigraphic unit, in the Southern Patagonian Ice Field, and also recognized in the upper parts of the surrounding cordillera (Fig. 1) characterized by very-low grade metamorphic rocks of Late Triassic age. It is the first mention of Triassic metamorphic rocks in Argentina.

We discard a volcanic origin to the Nunatak Viedma and we separate these rocks from similar rocks assigned to the Bahía de la Lancha Formation by age and lithology.

These Upper Triassic very low-to low-grade metamorphic rocks would integrate a metamorphic inlier that we propose to denominate "Nunatak Viedma Unit". It is a key element to understand the Patagonia-Antarctic Peninsula geometrical fit and the evolution of the early Mesozoic orogenic system. Given its broad range of detrital ages, it seems that the Viedma basin was probably a extensional retroarcbackarc basin, separated from trench-forearc basins such as the Chonos basin by an active volcanic arc emplaced along Central Patagonia and the Antarctic Peninsula. 


\section{Acknowledgments}

This work has been carried out thanks to the financial support of grants projects Agencia PICT-2013-1291; CONICET PIP 2014-2016 GI directed by M.G., Argentinian-French ECOS-SUD project A15U02 (CS and MG), and Proyecto FONDECYT No. 1161818 to MC. The authors are grateful to Parques Nacionales of Argentina for granting permission to access and study Los Glaciares National Park. RS is grateful to Dr. Pablo González (UNRN-CONICET) for comments and suggestions about the U-Pb geochronology. Likewise, we are thankful to both reviewers and the editor of the journal to spend time checking the work. This is contribution R-274 of the Instituto de Estudios Andinos Don Pablo Groeber (UBA-CONICET).

\section{Appendix A. Supplementary data}

Supplementary data to this article can be found online at https:// doi.org/10.1016/j.jsames.2018.12.015.

\section{References}

Angiboust, S., Cambeses, A., Hyppolito, T., Glodny, J., Monié, P., Calderón, M., Juliani, C., 2018. A 100-m.y.-long window onto mass-flow processes in the Patagonian Mesozoic subduction zone (Diego de Almagro Island, Chile). The Geological Society of America. https://doi.org/10.1130/B31891.1.

Angiboust, S., Hyppolito, T., Glodny, J., Cambeses, A., Garcia-Casco, A., Calderón, M., Juliani, C., 2017. Hot subduction in the middle Jurassic and partial melting of oceanic crust in Chilean Patagonia. Gondwana Res. 42, 104-125. https://doi.org/10. 1016/j.gr.2016.10.007.

Augustsson, C., Bahlburg, H., 2003a. Active or passive continental margin? Geochemical and Nd isotope constraints of metasediments in the backstop of a pre-Andean accretionary wedge in southernmost Chile $\left(46^{\circ} 30^{\prime}-48^{\circ} 30^{\prime} \mathrm{S}\right)$. In: McCann, T., Saintot, A. (Eds.), Tracing Tectonic Deformation Using the sedimentary record. Geological Society of London, Special Publications, pp. 253-268. https://doi.org/10.1144/GSL. SP.2003.208.01.12

Augustsson, C., Bahlburg, H., 2003b. Cathodoluminescence spectra of detrital quartz as provenance indicators for Paleozoic metasediments in southern Andean Patagonia. J. S. Am. Earth Sci. 16, 15-26. https://doi.org/10.1016/S0895-9811(03)00016-6.

Augustsson, C., Bahlburg, H., 2008. Provenance of late Palaeozoic metasediments of the Patagonian proto-Pacific margin (southernmost Chile and Argentina). Int. J. Earth Sci. 97, 71-88. https://doi.org/10.1007/s00531-006-0158-7.

Augustsson, C., Münker, C., Bahlburg, H., Fanning, M., 2006. Provenance of late Palaeozoic metasediments of the SW South American Gondwana margin: a combined $\mathrm{U}-\mathrm{Pb}$ and Hf-isotope study of single detrital zircons. J. Geol. Soc. 163, 983-995. https://doi.org/10.1144/0016-76492005-149.

Barbeau, D.L., Davis, J.T., Murray, K.E., Valencia, V., Gehrels, G.E., Zahid, K.M., Gombosi, J., 2009a. Detrital-zircon geochronology of the metasedimentary rocks of northwestern Graham Land. Antarct. Sci. 22 (1), 65-78.

Barbeau, D.L., Olivero, Swanson-Hysell, N.L., Zahid, K.M.E.B., Murray, K.E., Gehrels, G.E., 2009b. Detrital-zircon geochronology of the eastern Magallanes foreland basin: Implications for Eocene kinematics of the northern Scotia Arc and Drake Passage. Earth Planet. Sci. Lett. 284 (3-4), 489-503.

Blampied, J., Barberón, V., Ghiglione, M., Leal, P., Ramos, V., 2012. Disambiguation of the nunatak Viedma: a basement block previously confused as a volcanic center. In: XXIII Congreso Geológico Chileno. Antofagasta, Chile, pp. 380-382.

Bruhn, R.L., Stern, C.R., De Wit, J.J., 1978. Field and geochemical data bearing on the development of a Mesozoic volcanic-tectonic rift zone and back-arc basin in southernmost South America. Earth Planet. Sci. Lett. 41, 32-46.

Bucher, B., Grapes, R., 2011. In: Petrogenesis of Metamorphic Rocks, eighth ed. SpringerVerlag, Berlín 428 pp.

Burton-Johnson, A., Riley, T.R., 2015. Autochthonous v. accreted terrane development of continental margins: a revised in situ tectonic history of the Antarctic Peninsula. J. Geol. Soc. 172 (4), 822-825. https://doi.org/10.1144/jgs2014-110.

Calderón, M., Fildani, A., Hervé, F., Fanning, M.C., Weislogel, A., Cordani, U., 2007a. Late Jurassic bimodal magmatism in the northern sea-floor remnant of the Rocas Verdes basin, southern Patagonian Andes. J. Geol. Soc. 164, 1011-1022.

Calderón, M., Fosdick, J.C., Warren, C., Massone, H.-J., Fanning, C.M., Fadel Cury, L., Schwanethal, J., Fonseca, P.E., Galaz, G., Gaytán, D., Hervé, F., 2012. The low-grade Canal de las Montañas Shear Zone and its role in the tectonic emplacement of the Sarmiento Ophiolitic Complex and Late Cretaceous Patagonian Andes orogeny, Chile. Tectonophysics 524-525, 165-185. https://doi.org/10.1016/j.tecto.2011.12.034.

Calderón, M., Hervé, F., Fuentes, F., Fosdick, J.C., Sepúlveda, F., Galaz, G., 2016. Tectonic Evolution of Paleozoic and Mesozoic Andean Metamorphic Complexes and the Rocas Verdes Ophiolites in Southern Patagonia. In: Ghiglione, M.C. (Ed.), Geodynamic Evolution of the Southernmost Andes. Springer Earth System Sciences, pp. 7-36. https://doi.org/10.1007/978-3-319-39727-6_2.

Calderón, M., Hervé, F., Massonne, H.-C., Fanning, C.M., Chavez, A., Pankhurst, R., Kraus, S., 2010. Zircon crystallization in low-pressure anatectic systems: Constraints from Permian migmatites of Tierra del Fuego, southernmost South America. In: XII South
American Symposium on Isotope Geology. Brasília.

Calderón, M., Hervé, F., Massone, H.-J., Tassinari, C.G., Pankhurst, R., Godoy, E., Theye, T., 2007b. Petrogenesis of the Puerto Edén Igneous and Metamorphic

Complex,Magallanes, Chile: Late Jurassic syn-deformational anatexis ofmetapelites and granitoid magma genesis. Lithos 93, 17-38.

Calderón, M., Prades, C. Hervé, F., Avendaño, V., Fanning, C., Massonne, H., Theye, T. Simonetti, A., 2013. Petrological vestiges of the Late Jurassic-Early Cretaceous transition from rift to back-arc basin in southernmost Chile: New age and geochemical data from the Capitán Aracena, Carlos III, and Tortuga ophiolitic complexes. Geochem. J. 47, 201-217.

Carvalho, I., Fernandes, A.C., Andreis, R.R., Paciullo, F.V., Ribeiro, A., Trouw, R.A.J., 2005. The Ichnofossils of the Triassic Hope Bay Formation, Trinity Peninsula Group, Antarctic Peninsula. Ichnos 12, 191-200.

Castillo, P., Fanning, M.C., Hervé, F., Lacassie, J.P., 2016. Characterization and tracing of Permian magmatism in the south-western segment of the Gondwanan margin; $\mathrm{U}-\mathrm{Pb}$ age, $\mathrm{Lu}-\mathrm{Hf}$ and $\mathrm{O}$ isotopic compositions of detrital zircons from metasedimentary complexes of northern Antarctic Peninsula and western Patagonia. Gondwana Res. 36, 1-13. https://doi.org/10.1016/j.gr.2015.07.014.

Castillo, P., Fanning, M.C., Pankhurst, R.J., Hervé, F., Rapela, C.W., 2017. Zircon O- and Hf-isotope constraints on the genesis and tectonic significance of Permian magmatism in Patagonia. J. Geol. Soc. 174, 803-816. https://doi.org/10.1144/jgs2016-152.

Cawood, P.A., 2005. Terra Australis Orogen: Rodinia breakup and development of the Pacific and Iapetus margins of Gondwana during the Neoproterozoic and Paleozoic. Earth Sci. Rev. 69, 249-279. https://doi.org/10.1016/j.earscirev.2004.09.001.

Cawood, P.A., Buchan, C., 2007. Linking accretionary orogenesis with supercontinent assembly. Earth Sci. Rev. 69, 249-279. https://doi.org/10.1016/j.earscirev.2004.09. 001.

Cawood, P.A., Hawkesworth, C.J., Dhuime, B., 2012. Detrital zircon record and tectonic setting. Geology 40, 875-878. https://doi.org/10.1130/g32945.1.

Cawood, P.A., Kröner, A., Collins, W.J., Kusky, T.M., Mooney, W.D., Windley, B.F., 2009. Accretionary orogens through Earth history. Geological Society, London, Special Publications 318, 1-36. https://doi.org/10.1144/SP318.1.

Cawood, P.A., Nemchin, A.A., Freeman, M., Sircombre, K., 2003. Linking source and sedimentary basin: Detrital zircon record of sediment flux along a modern river system and implications for provenance studies. Earth Planet. Sci. Lett. 210 (1-2), 259-268. https://doi.org/10.1016/S0012-821X(03)00122-5.

Chang, Z., Vervoort, J.D., McClelland, W.C., Knaack, C., 2006. U-Pb dating of zircon by LA-ICP-MS. G-cubed 7, 1-14. https://doi.org/10.1029/2005GC001100.

Chemale Jr., F., Ramos, V.A., Naipauer, M., Girelli, T.J., Vargas, M., 2018. Age of basement rocks from the Maurice Ewing Bank and the Falkland/Malvinas Plateau. Precambrian Res. 314, 28-40. https://doi.org/10.1016/j.precamres.2018.05.026.

Cingolani, C.A., Varela, R., 1976. Investigaciones geológicas y geocronologicas en el extremo sur de la isla Gran Malvina, sector de Cabo Belgrano (Cabo Meredith), Islas Malvinas. Actas del sexto Congreso Geologico Argentino 1, 457-473.

Collins, W.J., 2002a. Nature of extensional accretionary orogens. Tectonics 21 (4), 1024 https://doi.org/10.1029/2000TC001272.

Collins, W.J., 2002b. Hot orogens, tectonic switching, and creation of continental crust. Geology 30 (6), 535-538. https://doi.org/10.1130/0091-7613(2002) $030<0535$ :HOTSAC $>2.0$.CO;2.

Dalziel, I.W.D., 1981. Back-arc extension in the southern Andes: a review and critical reappraisal. Philos. Trans. R. Soc. London, Ser. A 300, 319-335.

Dalziel, I.W.D., 1982. The pre-Jurassic history of the Scotia arc: a review and progress report. In: Craddock, C. (Ed.), Antarctic Geoscience. University of Wisconsin Press, pp. $111-126$.

Del Valle, R.A., Heredia, N., Montes, M., Nozal, F., Martín-Serrano, Á., 2007. El Grupo Trinity Peninsula en la Península Tabarin, extremo norte de la Península Antártica. Rev. Asoc. Geol. Argent. 62 (4), 498-505.

Dickinson, W.R., Gehrels, G.E., 2009. Use of U-Pb ages of detrital zircons to infer maximum depositional ages of strata: a test against a Colorado Plateau Mesozoic database. Earth Planet. Sci. Lett. 288 (1-2), 115-125.

Eagles, G., 2016. Tectonics Reconstructions of the Southernmost Andes and the Scotia Sea during the Opening of the Drake Passage. In: Ghiglione, M.C. (Ed.), Geodynamic Evolution of the Southernmost Andes. Springer Earth System Sciences, pp. 75-108. https://doi.org/10.1007/978-3-319-39727-6_4.

Echaurren, A., Oliveros, V., Folguera, A., Ibarra, F., Creixell, C., Lucasse, F., 2016. Early Andean tectonomagmatic stages in north Patagonia: insights from field and geochemical data. J. Geol. Soc. https://doi.org/10.1144/jgs2016-087.

Fang, Z-j., Boucot, A., Covacevich, V., Hervé, F., 1998. Discovery of Late Triassic fossils in the Chonos Metamorphic Complex, Southern Chile. Rev. Geol. Chile 25 (2), 165-173.

Faúndez, V., Hervé, F., Lacassie, J.P., 2002. Provenance studies of pre-late Jurassic metaturbidite successions of the Patagonian Andes, southern Chile. N. Z. J. Geol. Geophys. 45 (4), 411-425.

Ferraccioli, F., Jones, P.C., Vaughan, A.P.M., Leat, P.T., 2006. New aerogeophysical view of the Antarctic Peninsula: More pieces, less puzzle. Geophys. Res. Lett. 33, L05310. http://doi.org/10.1029/2005GL024636.

Forsythe, R.D., Mpodozis, C., 1979. El archipiélago de Madre de Dios, Patagonia Occidental, Magallanes: rasgos generales de la estratigrafía y estructura del basamento pre-Jurásico Superior. Rev. Geol. Chile 7, 13-29.

Forsythe, R.D., Mpodozis, C., 1983. Geología del Basamento pre-Jurásico Superior en el archipiélago Madre de Dios, Magallanes, Chile. Servicio Nacional de Geología y Minería, Boletín 39, 6.

Fosdick, J.C., Romans, B.W., Fildani, A., Bernhardt, A., Calderón, M., Graham, S.A., 2001 Kinematic evolution of the Patagonian retroarc fold-and-thrust belt and Magallanes foreland basin, Chile and Argentina, 51 30'S. GSA Bulletin 123 (9-10), 1679-1698. https://doi.org/10.1130/B30242.1.

Gärtner, A., Linnemann, U., Sagawe, A., Hofmann, M., Ullrich, B., Kleber, A., 2013. 
Morphology of zircon crystal grains in sediments-characteristics, classifications, definitions. Geol. Saxonica 59, 65-73.

Ghidella, M.E., Lawver, L.A., Marenssi, S., Gahagan, L.M., 2007. Modelos de cinemática de placas para Antártida durante la ruptura de Gondwana: una revisión. Rev. Asoc. Geol. Argent. 62 (4), 635-645.

Ghiglione, M., Likerman, J., Barberón, V., Giambiagi, B., Aguirre-Urreta, B., Suárez, F., 2014. Geodynamic context for the deposition of coarse-grained deep-water axial channel systems in the Patagonian Andes. Basin Res. 1-20. https://doi.org/10.1111/ bre.12061.

Ghiglione, M., Quinteros, J., Yagupsky, D., Bonillo-Martínez, P., Hlebszevtich, J., Ramos, V.A., Vergani, G., Figueroa, D., Quesada, S., Zapata, T., 2010. Structure and tectonic history of the foreland basins of southernmost South America. J. S. Am. Earth Sci. 29, 262-277. https://doi.org/10.1016/j.jsames.2009.07.006.

Ghiglione, M., Ramos, V.A., Cuitiño, J., Barberón, V., 2016. Growth of the Southern Patagonian Andes $\left(46-53^{\circ} \mathrm{S}\right)$ and Their Relation to Subduction Processes. In: Folguera, A., Naipauer, M., Sagripanti, L., Ghiglione, M., Orts, D., Giambiagi, L. (Eds.), Growth of the Southern Andes. Springer Earth System Sciences, pp. 201-240. https://doi.org/10.1007/978-3-319-23060-3_10.

Ghiglione, M., Suarez, F., Ambrosio, A., Da Poian, G., Cristallini, E., Pizzio, M., Reinoso, M., 2009. Structure and evolution of the Austral Basin fold-thrust belt, southern Patagonian Andes. Revista Asociación Geológica Argentina 65 (1), 215-236.

Giacosa, R., Fracchia, D., Heredia, N., 2012a. Structure of the Southern Patagonian Andes at $49^{\circ} \mathrm{S}$, Argentina. Geol. Acta 10 (3), 265-282.

Giacosa, R., Fracchia, D., Heredia, N., Pereyra, F., 2012b. Hoja Geológica 4972-III y 4975IV, El Chaltén, provincia de Santa Cruz. Instituto de Geología y Recursos MineralesServicio Geológico Minero Argentino. Boletín 399, Buenos Aires, pp. 86p.

Giambiagi, L., Tunik, M., Barredo, S., Bechis, F., Ghiglione, M., Alvarez, P., Drosina, M., 2009. Cinemática de apertura del sector norte de la cuenca Neuquina. Rev. Asoc. Geol. Argent. 65 (2), 278-292.

Gehrels, G., 2014. Detrital Zircon U-Pb Geochronology Applied to Tectonics. Annu. Rev. Earth Planet Sci. 42, 127-149. https://doi.org/10.1146/annurev-earth-050212124012.

Gehrels, G.E., Valencia, V.A., Ruiz, J., 2008. Enhanced precision, accuracy, efficiency, and spatial resolution of U-Pb ages by laser ablation-multicollector-inductively coupled plasma-mass spectrometry. G-cubed 9, 3. https://doi.org/10.1029/ 2007 GC001805.

Giacosa, R., Márquez, M., 2002. El basamento Paleozoico de la Cordillera Patagónica. In: Haller, M.J. (Ed.), Geología y Recursos Naturales de Santa Cruz. El Calafate (Buenos Aires), Relatorio del $15^{\circ}$ Congreso Geológico Argentino 1, 3, pp. 45-55.

Giacosa, R., Zubia, M., Sánchez, M., Allard, J., 2010. Meso-Cenozoic tectonics of the southern Patagonian foreland: Structural evolution and implications for $\mathrm{Au}-\mathrm{Ag}$ veins in the eastern Deseado Region (Santa Cruz, Argentina). J. S. Am. Earth Sci. 30, 134-150.

González, J., Oliveros, V., Creixell, C., Velásquez, R., Vásquez, P., Lucassen, F., 2017. The Triassic magmatism and its relation with the Pre-Andean tectonic evolution: Geochemical and petrographic constrains from the High Andes of north central Chile $\left(29^{\circ} 30^{\prime}-30^{\circ}\right.$ S). J. S. Am. Earth Sci (in press).

González, P.D., Sato, A.M., Naipauer, M., Varela, R., Basei, M.A.S., Sato, K., Llambías, E.J., Chemale, F., Castro Dorado, A., 2018. Patagonia-Antarctica Early Paleozoic conjugate margins: Cambrian synsedimentary silicic magmatism, U-Pb dating of Kbentonites, and related volcanogenic rocks. Gondwana Res. 63, 186-225.

González, P.D., Sato, A.M., Varela, R., Llambías, E.J., Naipauer, M., Basei, M., Campos, H., Greco, G.A., 2008. El Molino Plutón: A granite with regional metamorphism within El Jagüelito Formation, North Patagonian Massif. In: XI South American Symposium on Isotope Geology. San Carlos de Bariloche paper 41.

González, P.D., Sato, A.M., Varela, R., Greco, G.A., Naipauer, M., Llambías, E.J., Basei, M.A.S., 2014. Metamorfismo y estructura interna de la Formación El Jagüelito en el Arroyo Salado inferior, Macizo Norpatagónico, Río Negro. In: XIX Congreso Geológico Argentino. Córdoba, pp. 381-382.

González, P.D., Tortello, M.F., Damborenea, S.E., 2011. Early Cambrian Archaeocyathan limestone blocks in low-grade meta-conglomerate from El Jagüelito Formation (Sierra Grande, Río Negro, Argentina). Geol. Acta 9, 159-173. https://doi.org/10. 1344/105.000001650.

González, S.N., Greco, G.A., González, P.D., Sato, A.M., Llambías, E.J., Varela, R., 2016. Geochemistry of a Triassic dyke swarm in the North Patagonian Massif, Argentina. Implications for a postorogenic event of the Permian Gondwanide orogeny. J. S. Am. Earth Sci. 70, 69-82. https://doi.org/10.1016/j.jsames.2016.04.009.

Greco, G.A., González, S.N., Sato, A.M., González, P.D., Basei, M.A.S., Llambías, E.J., Varela, R., 2017. The Nahuel Niyeu basin: a Cambrian forearc basin in the eastern North Patagonian Massif. J. S. Am. Earth Sci. 79, 111-136. https://doi.org/10.1016/ j.jsames.2017.07.009.

Harrison, C.G.A., Barron, E.J., Hay, W.W., 1979. Mesozoic evolution of the Antarctic Peninsula and the southern Andes. Geology 7, 374-378.

Heredia, N., García-Sansegundo, J., Gallastegui, G., Farias, P., Giacosa, R.E., Alonso, J.L., Busquets, P., Charrier, R., Clariana, P., Colombo, F., Cuesta, A.,., Gallastegui, J., Giambiagi, L.B., González-Menéndez, L., Limarino, C.O., Martín-González, F., Méndez-Bedia, I., Pedreira, D., Quintana, L., Rodríguez-Fernández, L.R., RubioOrdóñez, A., Seggiaro, R.E., Serra-Varela, S., Spalletti, L.A., Cardó, R., Ramos, V.A., 2016. Evolución geodinámica de los Andes argentinos-chilenos y la Peninsula Antártica durante el Neoproterozico tardío y el Paleozoico. Trabajos de Geología, Universidad de Oviedo 36, 237-278.

Heredia, N., García-Sansegundo, J., Gallastegui, G., Farias, P., Giacosa, R.E., Hongn, F.D., Tubía, J.M., Alonso, J.L., Busquets, P., Charrier, R., Clariana, P., Colombo, F., Cuesta, A., Gallastegui, J., Giambiagi, L.B., González-Menéndez, L., Limarino, C.O., MartínGonzález, F., Pedreira, D., Quintana, L., Rodríguez-Fernández, L.R., Rubio-Ordóñez, A., Seggiaro, R.E., Serra-Varela, S., Spalletti, L.A., Cardó, R., Ramos, V.A., 2018. The
Pre-Andean phases of construction of the Southern Andes basement in Neoproterozoic-Paleozoic times. In: The Evolution of the Chilean-Argentinean Andes. Springer, Cham, pp. 111-131.

Hervé, F., 1988. Late Paleozoic subduction and accretion in southern Chile. Episodes 11 (3), 183-188.

Hervé, F., Nelson, E., Kawashita, K., Suárez, M., 1981a. New isotopic ages and the timing of orogenic events in the Cordillera Darwin, southernmost Chilean Andes. Earth Planet. Sci. Lett. 55, 257-265.

Hervé, F., Mpodozis, C., Davidson, J.A., Godoy, E.P., 1981b. Observaciones estructurales y petrográficas en el basamento metamórfico del archipielago de los Chonos, entre el canal King y el canal Ninualac, Aisen. Rev. Geol. Chile 13-14, 3-16.

Hervé, F., Calderón, M., Fanning, M., Kraus, S., Pankhurst, R.J., 2010a. SHRIMP chronology of the Magallanes Basin basement, Tierra del Fuego: Cambrian plutonism and Permian high-grade metamorphism. Andean Geol. 37 (2), 253-275.

Hervé, F., Calderón, M., Fanning, M., Pankhurst, R., Fuentes, F., Rapela, C.W., Correa, J., Quezada, P., Marambio, C., 2016. Devonian magmatism in the accretionary complex of southern Chile. J. Geol. Soc. 173, 587-602. https://doi.org/10.1144/jgs2015-163.

Hervé, F., Calderón, M., Faúndez, V., 2008. The metamorphic complexes of the Patagonian and Fuegian Andes. Geol. Acta 6 (1), 43-53. https://doi.org/10.1344/ 105.000000240.

Hervé, F., Fanning, C.M., 2001. Late Triassic zircons in metaturbidites of the Chonos Metamorphic Complex, southern Chile. Rev. Geol. Chile 28 (1), 91-104.

Hervé, F., Fanning, C.M., 2003. Early Cretaceous subduction of continental crust at the Diego de Almagro archipelago, southern Chile. Episodes 26, 4.

Hervé, F., Fanning, C.M., Pankhurst, R.J., 2003. Detrital zircon age patterns and provenance of the metamorphic complexes of southern Chile. J. S. Am. Earth Sci. 16, 107-123. https://doi.org/10.1016/S0895-9811(03)00022-1.

Hervé, F., Fanning, M., Pankhurst, R., Mpodozis, C., Klepeis, K., Calderón, M., Thomson, S.N., 2010b. Detrital zircon SHRIMP U-Pb age study of the Cordillera Darwin Metamorphic Complex of Tierra del Fuego: sedimentary sources and implications for the evolution of the Pacific margin of Gondwana. J. Geol. Soc. 167 (3), 555-568. https://doi.org/10.1144/0016-76492009-124.

Hervé, F., Miller, H., Pimpirev, C., 2006. Patagonia-Antarctica connections before Gondwana break-up. In: Fütterer, D.K., Dmaske, D., Kleinschmidt, G., Miller, H., Tessensohn, F. (Eds.), Antarctica: Contributions to global earth sciences. SpringerVerlag, pp. 217-227.

Hervé, F., Pankhurst, R.J., Fanning, C.M., Calderón, M., Yaxley, G.M., 2007. The South Patagonian batholith: 150 my of granite magmatism on a plate margin. Lithos 97 , 373-394. https://doi.org/10.1016/j.lithos.2007.01.007.

Heuret, A., Funiciello, F., Faccenna, C., Lallemand, S., 2007. Plate kinematics, slab shape and back-arc stress: A comparison between laboratory models and current subduction zones. Earth Planet. Sci. Lett. 256, 473-483.

Hyden, G., Tanner, P.W.G., 1981. Late Paleozoic-Early Mesozoic fore-arc basin sedimentary rocks at the Pacific margin in Western Antarctica. Geol. Rundsch. 70, 529-541.

Hyppolito, T., Angiboust, S., Juliani, C., Glodny, J., Garcia-Casco, A., Calderón, M.Y. Chopin, C., 2016. Eclogite-, amphibolite- and blueschist-facies rocks from Diego de Almagro Island (Patagonia): Episodic accretion and thermal evolution of the Chilean subduction interface during the Cretaceous. Lithos 264, 422-440. https://doi.org/10. 1016/j.lithos.2016.09.001.

Jarrad, R.D., 1986. Relations among subduction parameters. Rev. Geophys. 24 (2), 217-284.

Jacobs, J., Thomas, R.J., Armstrong, A., Henjes-Kunst, F., 1999. Age and thermal evolution of the Mesoproterozoic Cape Meredith Complex, West Falkland. J. Geol. Soc. 156, 917-928.

Jokat, W., Boebel, T., König, M.Y., Meyer, U., 2003. Timing and geometry of early Gondwana breakup. J. Geophys. Res. 108 (B9), 2428. https://doi.org/10.1029/ 2002JB001802.

Kilian, R., 1990. The Austral Andean Volcanic Zone (South Patagonian). In: International Symposium on Andean Geology, Grenoble, pp. 301-305.

Klepeis, K., Betka, P., Clarke, G., Fanning, M., Hervé, F., Rojas, L., Mpodozis, C., Thomson, S., 2010. Continental underthrusting and obduction during the Cretaceous closure of the Rocas Verdes rift basin, Cordillera Darwin, Patagonian Andes. Tectonics 29, TC3014. https://doi.org/10.1029/2009TC002610.

Kobayashi, C., Orihashi, Y., Hiarata, D., Naranjo, J.A., Kobayashi, M., Anma, R., 2010. Compositional variations revealed by ASTER image analysis of the Viedma Volcano, southern Andes Volcanic Zone. Andean Geol. 37 (2), 433-441.

König, M., Jokat, W., 2006. The Mesozoic breakup of the Weddell Sea. Journal of Geophysical Research-Solid Earth 111 (B12), 1-28.

Lacassie, J.P., 2003. Estudio de la Proveniencia Sedimentaria de los Complejos Metamórficos de los Andes Patagónicos (46- 51 Lat. S), mediante la aplicación de redes neuronales e isótopos estables. Ph.D. thesis. Universidad de Chile 173pp.

Lawver, L.A., Gahagan, L.M., Coffin, M.F., 1992. The development of paleoseaways around Antartica. In: In: Kennett, J.P., Warnke, D.A. (Eds.), The Antarctic Paleoenvironment: A Perspective on Global Change Part 1 56. A.G.U. Antarctic Research Series, Washington D.C., pp. 7-30.

Lawver, L.A., Gahagan, L.M., Dalziel, W.D., 1998. A tight fit-early Mesozoic Gondwana, a plate reconstruction perspective. Memoirs of the National Institute for Polar Research 53, 214-228.

Lliboutry, L., 1956. Nieves y glaciares de Chile. Fundamentos de glaciología. Ediciones de la Universidad de Chile, Santiago de Chile.

Likerman, J., Burlando, J.F., Cristallini, E., Ghiglione, M., 2013. Along-strike structural variations in the Southern Patagonian Andes: Insights from physical modelling. Tectonophysics 590, 106-120. https://doi.org/10.1016/j.tecto.2013.01.018.

Loske, W., Marquez, M., Giacosa, R., Pezzuchi, H., Fernández, M.I., 1999. U/Pb geochronology of pre-Permian basement rocks in the Macizo del Deseado, Santa Cruz 
province, Argentine Patagonia. In: XIV Congreso Geológico Argentino. Salta.

Ludwig, K.R., 2003. Using Isoplot/Ex, v.3. a Geochronological toolkit for Microsoft Excel 4 Berkeley Geochronology Center, Special publication.

Maloney, K.T., Clarke, G.L., Klepeis, K.A., Fanning, C.M., Wang, W., 2011. Crustal growth during back-arc closure: Cretaceous exhumation history of Cordillera Darwin, southern Patagonia. J. Metamorph. Geol. 29, 649-672.

Mazzoni, E., Coronato, A., Rabassa, J., 2010. The Southern Patagonian Andes: The Largest Mountain Ice Cap of the Southern Hemisphere. In: In: Migón, P. (Ed.), Geomorphological Landscapes of the World 12. Springer Sciences, pp. 111-121. https://doi.org/10.1007/978-90-481-3055-9_12.

Millar, I.L., Pankhurst, R.J., Fanning, C.M., 2002. Basement chronology of the Antarctic Peninsula: recurrent magmatism and anatexis in the Palaeozoic Gondwana Margin. J. Geol. Soc. 159, 145-157. https://doi.org/10.1144/0016-764901-020.

Miller, H., 2007. History of views on the relative positions of Antarctica and South America: A 100-year tango between Patagonia and the Antarctic Peninsula 41 USGS Numbered Series Short Research Paper. https://doi.org/10.3133/ ofr20071047SRP041.

Miller, H., Loske, W., Kramm, U., 1987. Zircon provenance and Gondwana reconstruction: U-Pb data of detrital zircons from Triassic Trinity Peninsula Formation metasandstones. Polarforschung 57 (1-2), 59-69.

Moreira, P., Fernández, R., Hervé, F., Fanning, C.M., Schalamuk, I.A., 2013. Detrital zircons U-Pb SHRIMP ages and provenance of La Modesta Formation, Patagonia Argentina. J. S. Am. Earth Sci. 47, 32-46. https://doi.org/10.1016/j.jsames.2013.05. 010.

Naipauer, M., Vujovich, G.I., Cingolani, C.A., McClelland, W.C., 2010. Detrital zircon analysis from the Neoproterozoic-Cambrian sedimentary cover (Cuyania terrane), Sierra de Pie de Palo, Argentina: Evidence of a rift and passive margin system? J. S. Am. Earth Sci. 29, 306-326.

Nelson, J., Gehrels, G., 2007. Detrital zircon geochronology and provenance of the southeastern Yukon-Tanana terrane. Can. J. Earth Sci. 44, 297-316.

Paces, J., Miller, J., 1993. Precise U-Pb ages of Duluth Complex and related mafic in trusions, northeastern Minnesota; geochronological insights to physical, petrogenetic, paleomagnetic, and tectonomagmatic processes associated with the $1.1 \mathrm{Ga}$ midcontinent rift system. J. Geophys. Res. 98 (B8), 13997-14013.

Pankhurst, R.J., 1982. Rb-Sr geochronology of Graham Land, Antarctica. Journal of the Geological Society of London 139, 701-711.

Pankhurst, R.J., Rapela, C.W., Fanning, C.M., Márquez, M., 2006. Gondwanide continental collision and the origin of Patagonia. Earth Sci. Rev. 76 (3-4), 235-257.

Pankhurst, R.J., Rapela, C.W., López de Luchi, M.G., Rapalini, A.E., Fanning, C.M., Galindo, C., 2014. The Gondwana connections of northern Patagonia. J. Geol. Soc. https://doi.org/10.1144/jgs2013-081.

Pankhurst, R.J., Rapela, C.W., Loske, W.P., Márquez, M., Fanning, C.M., 2003. Chronological study of the pre-Permian basement rocks of southern Patagonia. J. S Am. Earth Sci. 16 (1), 27-44.

Pankhurst, R.J., Riley, T.R., Fanning, C.M., Kelley, S.P., 2000. Episodic silicic volcanism in Patagonia and the Antarctic Peninsula: chronology of magmatism associated with the break-up of Gondwana. J. Petrol. 41 (5), 605-625.

Passchier, C.W., Trouw, R.A.J., 2005. In: Microtectonics, second ed. Springer-Verlag, Berlín 366 pp.

Permuy Vidal, C., Moreira, P., Guido, D.M., Fanning, C.M., 2014. Linkages between the southern Patagonia Pre-Permian basements: new insights from detrital zircons U-Pb SHRIMP ages from the Cerro Negro District. Geol. Acta 12 (2), 137-150.

Ramírez-Sánchez, E., Hervé, F., Kelm, U., Sassi, R., 2005. P-T conditions of metapelites from metamorphic complexes in Aysen, Chile. J. S. Am. Earth Sci. 19, 373-386.

Ramos, V.A., 2008. Patagonia: A Paleozoic continent adrift? J. S. Am. Earth Sci. 26 , 235-251. https://doi.org/10.1016/j.jsames.2008.06.002.

Ramos, V.A., 2010. The tectonic regime along the Andes: Present-day and Mesozoic regimes. Geol. J. 45, 2-25. https://doi.org/10.1002/gj.1193.

Ramos, V., Naipauer, M., 2014. Patagonia: where does it come from? J. Iber. Geol. 40 (2), 367-379.

Ramos, V.A., Cingolani, C., Chemale Jr., F., Naipauer, M., Rapallini, A., 2017. The Malvinas (Falkland) Islands revisited: The tectonic evolution of southern Gondwana based on U-Pb and Lu-Hf detrital zircon isotopes in the Paleozoic cover. J. S. Am. Earth Sci. 76, 320-345. https://doi.org/10.1016/j.jsames.2016.12.013.

Rapalini, A.E., Hervé, F., Ramos, V.A., Singer, S.E., 2001. Paleomagnetic evidence for a very large counterclockwise rotation of the Madre de Dios Archipelago, southern Chile. Earth Planet. Sci. Lett. 184, 471-478. https://doi.org/10.1016/S0012-821X (00)00339-3.

Rapalini, A.E., López de Luchi, M., Tohver, E., Cawood, P.A., 2013. The South American ancestry of the North Patagonian Massif: geochronological evidence for an autochthonous origin? Terra. Nova 25, 337-342. https://doi.org/10.1111/ter.12043.

Rapela, C.W., Pankhurst, R.J., Harrison, S.M., 1992. Triassic "Gondwana" granites of the Gastre district, North Patagonian Massif. Trans. R. Soc. Edinb. Earth Sci. 83, 291-304.

Rex, D.C., Tanner, P.W.G., 1982. Precambrian ages for gneisses at Cape Meredith in the Falkland Islands. In: Craddock, C. (Ed.), Antarctic Geoscience. University of Wisconsin Press, pp. 107-110.

Riley, T.R., Flowerdew, M.J., Pankhurst, R.J., Curtis, M.L., Millar, I.L., Fanning, M.C., Whitehouse, M.J., 2016. Early Jurassic magmatism on the Antarctic Peninsula and potential correlation with the Subcordilleran plutonic belt of Patagonia. J. Geol. Soc. 174, 365-376. https://doi.org/10.1144/jgs2016-053.

Riley, T.R., Flowerdew, M.J., Whitehouse, M.J., 2012. U-Pb ion-microprobe zircon geochronology from the basement inliers of eastern Graham Land, Antarctic Peninsula. J. Geol. Soc. 169 (4), 381-393.

Riley, T.R., Leat, P.T., Pankhurst, R.J., Harris, C., 2001. Origins of large volume rhyolitic volcanism in the Antarctic Peninsula and Patagonia by crustal melting. J. Petrol. 42 (6), 1043-1065. https://doi.org/10.1093/petrology/42.6.1043.
Riley, T.R., Flowerdew, M.J., Hunter, M.A., Whitehouse, M.J., 2010. Middle Jurassic rhyolite volcanism of eastern Graham Land, Antarctic Peninsula: age correlations and stratigraphic relationships. Geological Magazyne 147 (4), 581-595. https://doi.org/ 10.1017/S0016756809990720.

Saini-Eidukat, B., Beard, B., Bjerg, E.A., Gehrels, G., Gregori, D., Johnson, C., Migueles, N., Vervoort, J.D., 2004. Rb-Sr and U-Pb age systematics of the Alessandrini silicic complex and related mylonites, Patagonia, Argentina. In: Geological Society of America, Denver Annual Meeting. Denver, paper 88-14.

Schiffman, P., Day, H.W., 1999. Petrological methods for the study of very low-grade metabasites. In: Frey, M., Robinson, D. (Eds.), Low-Grade Metamorphism. Blackwell Science, pp. 108-141.

Schilling, M.E., Carlson, R.W., Tassara, A., Conceição, R.V., Bertotto, G.W., Vázquez, M. Muñoz, D., Jalowitzki, T., Gervasoni, F., Morata, D., 2017. The origin of Patagonia revealed by Re-Os systematics of mantle xenoliths. Precambrian Res. 294, 15-32. https://doi.org/10.1016/j.precamres.2017.03.008.

Serra-Varela, S., Giacosa, R., González, P., Heredia, N., Martín-González, F., Pedreira, D., 2016. Geología y geocronología del basamento paleozoico de los Andes Norpatagónicos en el área de San Martín de los Andes. In: IX Congreso Geológico de España, GEO-TEMAS. Huelva 16. pp. 431-434.

Shipton, E., 1960. Volcanic activity on the Patagonian Ice Cap. Geogr. J. 126 (4), 389-396.

Shipton, E., 1963. Land of Tempest: Travels in Patagonia 1958-1962, first ed. Hodder and Stoughton $222 \mathrm{pp}$.

Sláma, J., Kosler, J., Condon, D.J., Crowley, J.L., Gerdes, A., Hanchar, J.M., Horstwood, M.S.A., Morris, G.A., Nasdala, L., Norberg, N., Schaltegger, U., Schoene, B., Tubrett, M.N., Whitehouse, M.J., 2008. Plesovice zircon - a new natural reference material for $\mathrm{U}-\mathrm{Pb}$ and $\mathrm{Hf}$ isotopic microanalysis. Chem. Geol. 249, 1-35.

Söllner, F., Miller, H., Hervé, M., 2000. An Early Cambrian granodiorite age from the preAndean basement of Tierra del Fuego (Chile): the missing link between South America and Antarctica? J. S. Am. Earth Sci. 13, 163-177. https://doi.org/10.1016/ S0895-9811(00)00020-1.

Spencer, C.J., Kirkland, C.L., Taylor, R.J.M., 2016. Strategies towards statistically robust interpretations of in situ U-Pb zircon geochronology. Geoscience Frontiers 7, 581-589. https://doi.org/10.1016/j.gsf.2015.11.006.

Spikings, R., Reitsma, M.J., Boekhout, F., Mišković, A., Ulianov, A., Chiaradia, M., Gerdes, A., Schategger, U., 2016. Characterisation of Triassic rifting in Peru and implications for the early disassembly of western Pangaea. Gondwana Res. 35, 124-143.

Stern, R.J., 2002. Subduction zones. Rev. Geophys. 40 (4), 1012. https://doi.org/10. 1029/2001RG000108.

Stern, C.R., de Wit, M.J., 2003. Rocas Verdes ophiolites, southernmost South America: remnants of progressive stages of development on oceanic-type crust in a continental margin back-arc basin. In: Dilek, Y., Robinson, P.T. (Eds.), Ophiolites in Earth History. Geological Society, Special Publications, pp. 1-19.

Suárez, M., 1976. Plate-tectonic model for southern Antarctic Peninsula and its relation to southern Andes. Geology 4, 211-214. https://doi.org/10.1130/0091-7613(1976) $4<211$ :PMFSAP > 2.0.CO;2.

Tera, F., Wasserburg, G.J., 1972. U-Th-Bb systematics in three Apollo 14 basalts and the problem of initial $\mathrm{Pb}$ in lunar rocks. Earth Planet. Sci. Lett. 14, 281-304.

Thomas, R.J., Jacobs, J., Eglintong, B.M., 2000. Geochemistry and isotopic evolution of the Mesoproterozoic Cape Meredith Complex, West Falkland. Geol. Mag. 137 (5), 537-553.

Thomson, S.N., Hervé, F., 2002. New time constraints for the age of metamorphism at the ancestral Pacific Gondwana margin of souther Chile (42-52 ${ }^{\circ}$ S). Rev. Geol. Chile 28 (2), 255-271.

Trouw, R.A.J., Passchier, C.W., Simões, L.S.A., Andreis, R.R., Valerianos, C.M., 1997. Mesozoic tectonic evolution of the South Orkney Microcontinent, Scotia Arc, Antarctica. Geol. Mag. 134 (3), 383-401.

Uyeda, S., Kanamori, H., 1979. Back-arc opening and the mode of subduction. J. Geophys Res. 84 (3), 1049-1061.

Varela, R., Basei, M.A.S., Cingolani, C.A., Siga Jr., O., Passarelli, C.R., 2005. El basamento cristalino de los Andes norpatagónicos en Argentina: geocronología e interpretación tectónica. Rev. Geol. Chile 32 (2), 167-187.

Vaughan, A.P.M., Livermore, R.A., 2005. Episodicity of Mesozoic terrane accretion along the Pacific margin of Gondwana: implications for superplume-plate interactions. In: Vaughan, A.P.M., Leat, P.T., Pankhurst, R.J. (Eds.), Terrane Processes at the Margins of Gondwana. Geological Society, Special Publications, pp. 1-21.

Vaughan, A.P.M., Storey, B.C., 2000. The eastern Palmer Land shear zone: A new terrane accretion model for the Mesozoic development of the Antarctic Peninsula. J. Geol. Soc. 157, 1243-1256. http://doi.org/10.1144/jgs.157.6.1243.

Vaughan, A.P.M., Eagles, G., Flowerdew, M.J., 2012. Evidence for a two-phase Palmer Land event from crosscutting structural relationships and emplacement timing of the Lassiter Coast Intrusive Suite, Antarctic Peninsula: Implications for mid-Cretaceous Southern Ocean plate configuration. Tectonics 31, TC1010.

Wareham, C.D., Pankhurst, R.J., Thomas, R.J., Storey, B.C., Grantham, G.H., Jacobs, J., Eglington, B.M., 1998. Pb, Nd, and Sr Isotope Mapping of Grenville-Age Crustal Provinces in Rodinia. J. Geol. 106, 647-659. https://doi.org/10.1086/516051.

Wetherill, G.W., 1956. Discordant uranium-lead ages, I. Transactions. American Geophysical Union 37 (3), 320-326. https://doi.org/10.1029/TR037i003p00320.

Wever, H.E., Millar, I.L., Pankhurst, R.J., 1994. Geochronology and radiogenic isotope geology of Mesozoic rocks from eastern Palmer Land, Antarctic Peninsula: crustal anatexis in arc-related granitoid genesis. J. S. Am. Earth Sci. 7 (1), 69-83.

Willan, R.C.R., Pankhurst, R.J., Hervé, F., 1994. A probable Early Triassic age for the Miers Bluff Formation, Livingston Island, South Shetland Islands. Antarct. Sci. 6 (3), 401-408.

Willner, A., Hervé, F., Massonne, H.J., 2000. Mineral chemistry and pressure-temperature evolution of two contrasting high-pressure-low-temperature belts in the Chonos 
Archipelago, Southern Chile. J. Petrol. 41 (3), 309-330. https://doi.org/10.1093/ petrology/41.3.309.

Willner, A.P., Sepúlveda, F.A., Hervé, F., Massonne, H.-J., Sudo, M., 2009. Conditions and timing of pumpellyite-actinolite-facies metamorphism in the Early Mesozoic frontal accretionary prism of the Madre de Dios Archipelago (Latitude $50^{\circ} 20^{\prime}$ S; Southern Chile). J. Petrol. 50, 2127-2155. https://doi.org/10.1093/petrology/egp071.

Williams, I.S., 1998. U-Th-Pb geochronology by ion microprobe. Rev. Econ. Geol. 7, 1-35. Zaffarana, C.B., Somoza, R., López de Luchi, M., 2014. The Late Triassic Central Patagonian Batholith: Magma hybridization, 40Ar/39Ar ages and thermobarometry.
J. S. Am. Earth Sci. 55, 94-122. https://doi.org/10.1016/j.jsames.2014.06.006. Zaffarana, C.B., Somoza, R., Orts, D.L., Mercader, R., Boltshauser, B., González, V.R., Puigdomenech, C., 2017. Internal structure of the Late Triassic Central Patagonian batholith at Gastre, southern Argentina: Implications for pluton emplacement and the Gastre fault system. Geosphere 13, 6. https://doi.org/10.1130/GES01493.1.

Zerfass, H., Ramos, V.A., Ghiglione, M.C., Naipauer, M., Belotti, H.J., Carmo, I.O., 2017 Folding, thrusting and development of push-up structures during the Miocene tectonic inversion of the Austral Basin, Southern Patagonian Andes ( $50^{\circ} \mathrm{S}$ ).

Tectonophysics 699, 102-120. 